\title{
BROWN V LEYDS NO (1897) 4 OR 17: A CONSTITUTIONAL DRAMA IN FOUR ACTS. \\ ACT FOUR: KOTZÉ DELIVERS HIS JUDGEMENT, KRUGER DISMISSES HIM, MILNER PREPARES FOR WAR AND BROWN SEEKS INTERNATIONAL REDRESS
}

\section{Derek van der Merwe*}

\section{ABSTRACT}

This is the fourth and final article in a series on the historical and jurisprudential background to the well-known case of Brown $v$ Leyds NO (1897) 4 OR 17, based on the book, Brown v Leyds, Who Has the King's Voice (2017, LexisNexis). It discusses Chief Justice Kotzé's judgement in Brown in detail and the major political fallout it generated. Kotze's judgement was his expression of the ultimate authority of the 1858 Grondwet (Constitution) in the Zuid-Afrikaansche Republiek, the judicial interpretation of which transcended legislative and executive authority in the state. In finding for Brown and against the state, Kotzé asserted in open court the primacy of judicial interpretation of the Grondwet over the highest authority of the Volksraad

* Emeritus Professor of Law, University of Johannesburg. 
(the legislative authority), that is, the sovereign authority that the state president and his Volksraad had always regarded as an unimpeachable constitutional guarantee. The judgement caused unprecedented political upheaval. It led to the state president dismissing the chief justice from office. It also served to confirm the conviction of imperial Britain that the Boers could not be trusted to govern the land in which the world's largest gold deposits lay. The chief justice's dismissal was a significant contributor to the outbreak of the Anglo-Boer War in October 1899. Robert Brown, in whose favour Kotzé had found, was unable to exert the rights to the claims on the Witfontein gold diggings the Supreme Court had found he was entitled to. He took his cause to the United States Senate. After the Anglo-Boer War, the United States took up Brown's cause with Great Britain. Great Britain refused to acknowledge any obligation to Brown to recompense him for the loss of his claims. The dispute dragged on for years. Only in 1923 did an international arbitral tribunal, presided over by Henry Fromageot, finally dispose of the matter, finding for Great Britain and therefore against Brown.

Keywords: 1858 Grondwet; Supreme Court; constitution; constitutional democracy; Volksraad; Boers; supreme authority; sovereign authority; highest authority; King's voice; volk; judicial independence; testing right; Volksraad resolutions; Paul Kruger; John Kotzé; Robert Brown; Alfred Milner; Joseph Chamberlain; United States; Great Britain; international arbitration; Anglo-Boer War

\section{Introduction}

In May 1895 Chief Justice Kotzé made obiter comments in his judgement in Hess $v$ The State. ${ }^{1}$ He stated that it was clearly his duty as a judge, "above all", to respect and maintain the Grondwet, and that it was incumbent upon the judicial authority to test whether a law passed by the legislative authority was valid in accordance with constitutional provisions. He found that Law 11 of 1893, regulating defamation by the press, did not pass the test of validity and that, therefore, had it been necessary for the judgement to do so, he would have struck down the law as unconstitutional. He acknowledged in his obiter remarks that his view on the judicial testing right had changed. $^{2}$

Two months later, on 22 July, an American mining engineer and would-be gold-digger, Robert Brown, instituted an action in the Supreme Court, in which he sought an order declaring that his pegging off of 1200 gold claims on the proclaimed Witfontein goldfield on the western edge of the Witwatersrand, was in fact valid. At issue was the validity of the decision of Paul Kruger's Executive Council to suspend the proclamation of the Witfontein goldfield (and therefore also of Brown and others' right to mine their pegged-off claims) by resolution, until better arrangements for the

1 (1895) 2 OR 112 at 114-116.

2 See the discussion of Kotzé's obiter comments in Van der Merwe 2018 (1): 126-128. 
public peace could be made. The resolution, published in the Government Gazette, was confirmed by the (First and Second) Volksraad in terms of a resolution some ten days later. At issue, therefore, was the competence of the Executive Council and, later, of the Volksraad, to make (and to repeal) legislative enactments by nonlegislative means (through resolutions) and therefore to make law in a manner not prescribed by the Grondwet. ${ }^{3}$

Kruger had been aware of Kotzé's assertion of the judicial testing right in his obiter comments in May in Hess and recognised, in Brown's litigation in July, that the manner under which the proclamation of the Witfontein goldfields had been suspended would create an opportunity for Kotzé to assert the testing right, this time in a substantive judgement. He therefore invited Kotzé to meet with him on 6 September, before argument had been heard in the Brown matter, to try to persuade him not to adopt an approach that would have severe repercussions. The meeting did not go well. Kruger said it was inconceivable that a court could declare the legislation of the Volksraad invalid (only the volk - the people - could do so); he appealed to the sense of brotherhood that existed between them; and he made it clear that he would have to suspend the judge if he did not climb down from his high horse. Kotzé would not be persuaded: he told Kruger that he would continue to follow the dictates of his conscience and the law; anyway, the volk was too sensible to allow conflict to exist between the legislature and the judiciary. ${ }^{4}$

Kotzé's determination to go the distance in this matter of constitutional principle was evident in a matter heard by the Supreme Court in early December, some three weeks after Brown's application was argued before Kotzé CJ, Ameshoff J and Morice J from 15 to 19 November. ${ }^{5}$ The Court found that an acting judge, Esser, had been appointed irregularly by State Secretary Leyds, that is, not in accordance with the provisions of the Grondwet, and that no consequences could be attached to the subsequent discharge of his judicial duties. In his judgement, Kotzé reiterated what had by now become his mantra, namely that faithful observance of the Grondwet and its principles was the "only safeguard which the people have". ${ }^{6}$

In the last quarter of 1895 the developing tension between Kruger and Kotzé on the supremacy of the Grondwet and the concomitant right of the judiciary to test the validity of laws passed by the Volksraad was overshadowed by political events that threatened the very fabric of the Boer state. At stake was the extent and nature of political reform in the Republic. For Kruger and his Boer supporters, the independence

3 On the circumstances surrounding Brown's action, see idem 128-129.

4 Kotzé, clearly sensing conflict ahead, had made careful notes of this meeting: see Editorial 1898b: 90-93. See, also, the discussion in Van der Merwe 2018: 129-130.

5 The opposing counsel represented the very best of the Republican Bar: for Brown appeared Wessels and Curlewis (both later to become chief justices of the Union of South Africa) and for the state appeared Esselen, the leader of the Republican Bar and at the time state attorney. See Snuif v The State (1895) 2 OR 294 at 297. See, further, Van der Merwe 2018: 130. 
of the Boer nation was non-negotiable and therefore electoral and economic reforms were always going to be piecemeal and insubstantial. He had a deep-seated mistrust of the British ${ }^{7}$ and so his opposition to British influence would always be heated and intransigent. The progressive Boers aligned themselves with the moderates among the uitlanders (the non-Boer foreigners in the mining and related industries) and sought substantive franchise reform, more competitive, less draconian economic regulation and the incorporation of the South African Republic ${ }^{8}$ in a southern African federation of African states and colonies under British influence. The imperialists wanted nothing less than full British paramountcy over the whole of southern Africa and therefore actively sought to destroy the independence of the Transvaal. The swirl of political undercurrents was, of course, caused and determined by the vast riches of the Transvaal goldfields and the aim to exercise ultimate control over them. Intrigue, conspiracy, espionage and open hostility between Boer and uitlander had been fomenting throughout 1895 and reached boiling point at the end of the year. ${ }^{9}$ Robert Brown, too, who had arrived at the Witwatersrand in 1894, was a participant in the unfolding events of 1895: as a Boer sympathiser and advocate for reform rather than for revolution, he still had no hesitation in litigating against the Kruger government. ${ }^{10}$ These political tensions would reach their apogee in the Jameson Raid of 29 December 1895 to 2 January 1896. The Raid had a profound influence on political events in the years leading up to the outbreak of the Anglo-Boer War in October 1899. It also had a significant influence on John Kotzé.

\section{The Jameson Raid and its influence on John Kotzé}

The chief instigator of the Raid was Cecil John Rhodes, who started his planning for a military overthrow of Kruger's government at Groote Schuur in Cape Town in June 1895. ${ }^{11}$ The plan was for Dr Leander Jameson, then administrator of the British South Africa Chartered Company of Mashonaland, to lead a military incursion into the Republic from Pitsani in the Bechuanaland Protectorate on the Republic's western border. They would ride into Johannesburg, there joining forces

7 His state secretary and right-hand man, Willem Leyds, shared this deep mistrust of the British: see Bossenbroek 2012: 87-88.

8 The official name of the Republic was the "Zuid-Afrikaansche Republiek" (South African Republic). British officials continued to use the term "Transvaal", the name they had given to the Republican territory upon annexation in 1877. For purposes of this contribution, these names will therefore be used interchangeably.

9 See, among many, Marais 1961: 46-135; Meredith 2007: 291-310; Van der Merwe 2015: 48-54; and, most recently, Van Onselen 2017: 179-283.

10 See Van Onselen 2017: 114-116, 180, 193-194, 198 and 203-204.

11 The most recent, comprehensive discussion of the events leading up to the Raid, the Raid itself and its aftermath is by Van Onselen 2017: 101ff. Recent publications on the Jameson Raid also include Meredith 2007: 311-351; Bossenbroek 2012: 84-89; and Van der Merwe 2015: 54-62. 
with uitlanders led by a group who called themselves "Reformers" (Lionel Phillips, John Hays Hammond, Charles Leonard, Frank Rhodes - Cecil's brother - and George Farrar) and the leaders of a sixty-four-strong "Reform Committee". There was frenzied planning in Johannesburg in preparation for the grand revolution. The National Union, established in 1892 to serve as an increasingly strident voice for uitlander political opinion, ${ }^{12}$ published a lengthy manifesto of uitlander grievances and demands on 26 December. ${ }^{13}$ It was written by Charles Leonard, its chairman, and brother of Jim Leonard QC, a leading member of the Bar. Among its demands was for an independent judiciary and a constitution that was not susceptible to ready amendment. It also referenced Brown's Witfontein litigation and lamented the unconstitutional interference by the legislature in established rights. Clearly, Charles Leonard and John Kotzé were like-minded in this regard. Alfred Beit, the richest and most influential of the Randlords, would finance the venture. ${ }^{14}$

The entire operation was an ignominious failure. The planned uprising in Johannesburg never took place and Jameson's 500-odd troops were surrounded by Republican forces near Doornkop, on the western edge of modern Soweto, and forced to surrender on 2 January 1896. Coincidentally, the place where Jameson's troops were forced to surrender was very close to the place at which Robert Brown had sought to purchase his licences to peg off claims on the Witfontein farm. ${ }^{15}$

John Kotzé was on holiday in Cape Town when informed - on Christmas Day - that a crisis was imminent in the Republic and returned to Pretoria the next day. State Secretary Leyds was in Europe at the time, so Kruger recruited Kotzé and Judges Jorissen and Ameshoff to serve as advisors as the events from 30 December unfolded. Kotzé was in his element in serving Kruger during the coming days. ${ }^{16} \mathrm{He}$ was a member of a delegation comprising himself, Judge Ameshoff and Jan Kock (long-standing member of the Executive Council) that met with Lionel Phillips and three other so-called Reformers on Monday 1 January 1896, when Boer forces first engaged with Jameson and his men, to listen to their grievances; he communicated with JH Hofmeyr, leader of the influential Afrikaner Bond in the Cape Colony and looked after the British High Commissioner, Sir Hercules Robinson, when the latter came to Pretoria to mediate between the parties. Also acting as advisor on foreign affairs in Leyds's absence, he convinced Kruger not to participate in a conference of European nations organised by Kaiser Wilhelm of Germany (at Leyds's instigation) designed to secure the Republic's independence, arguing that it would unnecessarily

12 See Marais 1961: 56-57; and Van der Merwe 2015: 39-40.

13 A Dutch translation of the manifesto appears in Van Oordt 1898: 629-642.

14 See Meredith 2007: 311.

15 See Nathan 1941: 351.

16 He describes his participation in these events as Kruger's advisor in some detail in Kotzé 1941: 241-256. 
further inflame British passions and goad Great Britain and Germany into open confrontation.

In his memoirs, Kotzé is full of praise for the manner in which Kruger remained master of the situation and defused the crisis through negotiations with Robinson. ${ }^{17}$ The Reform Committee surrendered, uitlanders who gave up their weapons were pardoned, Jameson and his officers would stand trial in England, and Jameson would be sentenced to fifteen months' imprisonment (although he served only four months and became a popular hero for standing up to the dastardly Boers). ${ }^{18}$ In addition, Kruger managed to placate the excitable Boers who were spoiling for another Majuba. ${ }^{19}$ Undoubtedly, Kotzé was as close to Kruger as he had ever been - as close, in any event, to the brotherhood Kruger had spoken of in his September meeting with Kotzé.

Rhodes resigned as Prime Minister of the Cape Colony. Kruger had all sixtyfour members of the Reform Committee arrested on 9 and 10 January 1896. On the same day, he issued a so-called forgive-and-forget proclamation..$^{20}$ In it he informed the Johannesburg uitlanders that he would forgive them their treasonous activities if they would only but work with the government. He also promised them that Johannesburg would be given full municipal status and that they would have their own mayor and a measure of self-government. Little came of these promises, though. Some saw in this proclamation the hand of John Kotzé, although Jorissen, implausibly, claimed the credit. ${ }^{21}$

Joseph Chamberlain, British secretary of state for the colonies and undoubtedly aware of Rhodes' machinations in the run-up to the abortive raid, far from eating humble pie after the incident, went on a full-scale diplomatic offensive against the Republic. ${ }^{22}$ In March 1896, he had a long despatch on Transvaal affairs drafted, in which he attached moral culpability to Kruger for not heeding the many uitlander grievances. He also invited Kruger to attend a conference in London to discuss Transvaal and broadly South African affairs. Kotzé, ever desirous of compromise, counselled Kruger to attend the conference. Initially willing to do so, he eventually declined, persuaded by Leyds (much to Kotzé's chagrin, one imagines) that if the Republic could not co-determine the conference themes, there was no point in

17 See Kotzé 1941: 252-256.

18 Jameson returned to southern Africa after his imprisonment. He participated in the Anglo-Boer War, became a member of the Cape Parliament in 1900, leader of the Progressive Party in the Cape in 1903, Prime Minister of the Cape Colony from 1904 to 1908 and the first leader of the opposition in the Union Parliament. He died in London in 1917. See Dictionary of SA Biography vol 3: 438-442 at 441-442.

19 See Nathan 1941: 357-362; Meredith 2007: 346-348; and Bossenbroek 2012: 88-89.

20 On which, see Jorissen 1897: 33-35; Nathan 1941: 362-363.

21 See Jorissen 1897: 142; and Nathan 1941: 364.

22 See Meredith 2007: 346. 
going. ${ }^{23}$ Leyds had returned to Pretoria at the end of $\mathrm{March}^{24}$ and could therefore stymie any influence Kotzé might have hoped to continue exercising over Kruger.

The sixty-four so-called Reformers were tried on charges of treason on 24 April 1896. The trial judge was Reinhold Gregorowski, appointed specially for the purpose, as all the Republican judges were involved in the affair in one way or another, acting as advisors to Kruger during the rebellion..$^{25}$ The leaders (Phillips, Hays Hammond, Farrar and Frank Rhodes - Charles Leonard had fled the country), having pleaded guilty, were found guilty of treason by Gregorowski $\mathrm{J}$ and sentenced to death on 28 April. The other reformers pleaded guilty to a lesser charge of treason, and were found guilty and sentenced to differing terms of imprisonment, fines and periods of banishment from the Republic. Later, Gregorowski wrote that he knew at the time of sentencing that the death sentences imposed by him would be commuted, since Chief Justice Kotzé had told him so. ${ }^{26}$ This in fact happened. Within two weeks, Kruger commuted the death sentences (though not without stern resistance from Leyds and General Piet Joubert, the commandant-general), first to terms of imprisonment and later to fines (the fines were paid by Rhodes and Beit). ${ }^{27}$

John Kotzé had used the opportunity given him by Leyds's absence to make himself indispensable to President Kruger and to indulge in the high politics he had always yearned for. However, his politics of compromise did not yield the results his political ambitions demanded. He was characterised in February by one senior foreign official as "an ambitious, intriguing man who wants to be President, or K.C.M.G., or both". ${ }^{28}$ When Leyds returned to Pretoria at the beginning of April and resumed his role as prime minister to Kruger, the opportunity for Kotzé to exhibit statesmanship had come and gone.

This was bad enough for Kotzé, but worse still - the newly revised Grondwet passed by the First Volksraad in early June did not meet his expectations. ${ }^{29}$ Revisions to the Grondwet had been under discussion since 1893 and Kotzé and his fellow judges had actively provided input into the review process..$^{30}$ Importantly, Kotzé had proposed that the Grondwet be amended to provide for a special procedure that would elevate it to a higher plane than ordinary legislation. Such an elevation was crucial to Kotzé's cause for a true constitutional democracy as practised in the United

24 Van Niekerk 1985: 147.

25 On Gregorowski, see Roberts 1942: 362. He had been a judge in the Orange Free State (he was appointed a judge when not quite twenty-five years old) and was State Attorney of the OFS at the time of his special appointment.

26 See Kahn 1959: 56 n 53.

27 On the trial, see Nathan 1941: 373-376; Van Niekerk 1985: 147-148; Meredith 2007: 350; Bossenbroek 2012: 88; and Van Onselen 2017: 327-329.

28 See Marais 1961: 140.

29 The text of this revised Grondwet appears in Schagen van Leeuwen 1897: 35-59.

30 On which, see Van der Merwe 2018: 123. 
States, the universal lodestar for the pursuit of republican politics. It meant, crucially, that the constitutionally guaranteed "highest authority" of the Volksraad did not also mean that it was the sovereign authority - that it had the King's voice. Kotzé, then, no doubt preparing his judgement in the Brown matter, would have noted this with much disappointment.

There was more disappointment for Kotzé at this time. A letter, written by Phillips to Alfred Beit in 1894 regarding Judge Benny de Korte's profligacy and inability to pay his debts, had come into the possession of the investigators who were sifting through the documents of the Reformers, in search of evidence of treasonous activities. The letter was presented by Leyds to the Executive Council in May, who immediately ordered De Korte's suspension and the appointment of a special court to hear charges of misconduct in his judicial capacity against De Korte. The special court, comprising five Volksraad members and judges Kotzé, Ameshoff and Morice, met on 10 June 1896 to hear the charges against De Korte. Although the court found that he had not acted improperly in his judicial capacity, the evidence presented at the hearing was a damning indictment of De Korte's behaviour. He resigned his office two days later. It was a major blow for Kotzés efforts to depict the judiciary as the final arbiter of the constitutional integrity of the organs of state, if its secondmost senior judge displayed such financial impropriety. ${ }^{31}$

Feeding off the statesmanship he had displayed in his handling of the Jameson Raid and its consequences, and undaunted by the strong political pressure Joseph Chamberlain was placing on him for meaningful political reforms, ${ }^{32}$ Paul Kruger later in that year continued to publicly preach his political mantra. It remained very different from the mantra adopted by John Kotzé. In the First Volksraad and again at a luncheon in his honour in early December, he reiterated that the Koningstem (the King's voice) belonged to the volk (the people), that is to the majority of the enfranchised burghers (those who had voted him and his supporters into office); on them rested the burden of divinely imposed statehood. ${ }^{33}$ Paul Kruger, with his populist insistence that the state was governed, and its destiny determined, by the volkstem (the will of the majority of the people), was ideologically as far removed as ever from John Kotzé and his insistence on constitutional democracy as the ultimate guarantor of people's freedoms. Kotzé fretted at this time, convinced that Kruger and the Volksraad needed better guidance on legislation passed in this year than State Secretary Leyds was providing to him..$^{34}$

31 On Phillips's letter, De Korte's financial impropriety and the special court and its proceedings, see Van der Merwe 1979: 243-245 and 249-251. The composition and terms of reference of the special court were captured in the new Grondwet, published in the Government Gazette only a week earlier: see Schagen van Leeuwen 1897: 45-46.

32 On which, see Van Oordt 1898: 760-762 and 768-769; Marais 1961: 122-135; and Van Niekerk 1985: $150-151$ and 153-158.

33 See Kleynhans 1966: 23 nn 7 and 11, and 26 n 29.

34 See Marais 1961: 140. 
Political events since the Jameson Raid clearly influenced the judgement in the Brown matter that he would belatedly hand down in January 1897, fully fourteen months after hearing argument. No reason is given in any of the judgements for this long delay. One can but assume that Kotzé, mindful of the effect his judgement would have on political events in the Republic, delayed the handing down of the judgement as long as possible, in order to seek the most opportune time, politically speaking, for him to do so.

\section{$3 \quad$ Brown v Leyds NO (1897) 4 OR 17}

\section{The judgement of Kotzé CJ}

Kotzé CJ and his fellow judges, Ameshoff $\mathrm{J}$ and Morice $\mathrm{J}$, handed down their judgements on 22 January 1897, a full eighteen months after Robert Brown had first instituted his action.

Kotzé CJ first recounted the facts. ${ }^{35}$ There was no question, he said, that the relevant portion of Witfontein farm had become a duly proclaimed public digging on 19 July 1895 . In order for its proclamation to be suspended, another proclamation needed to be passed in accordance with the provisions of the Gold Law. The proclamation passed by the Executive Council and published on 20 July did not meet these requirements. That is why the Second Volksraad passed its resolution on 26 July, affirming the content of the 20 July proclamation and thus denying legal redress to Brown and others who had pegged off claims on 19 July. That is also why the First Volksraad on 1 August resolved to affirm the resolution of the Second Volksraad.

The first question in law was therefore whether the Second Volksraad resolution of 26 July (later confirmed by the First Volksraad) had the force of law. ${ }^{36}$ Section 32 of Law 4 of 1890 (the law that provided for the establishment of the Second Volksraad) had made it clear that the First and Second Volksraad had the same legislative competence. That is to say, any law or resolution passed by it and duly published in the Government Gazette under the authority of the state president, was valid law, except if the volk clearly indicated their displeasure. The fact that all of these procedural conditions had been met, did not dispose of the matter. Two questions needed to be answered. First, did the resolution, which amounted to an implied amendment of the Gold Law, count as the declaration of the will of the legislature in the form of a law? Second, even if the answer to the first question is provided by the express statement in section 32 that a resolution of the Second Volksraad, duly published, is valid law, did section 32 constitute valid law?

35 His judgement appears at 22-41 of the published report. The facts are recounted in Van der Merwe 2018: 128-129.

36 Idem 23. 
In seeking an answer to these questions, Kotzé CJ began by examining the history of the approval of the Grondwet on 18 February 1858. His conclusion was that the Grondwet was not simply another law of the Volksraad. In section 12 it proclaimed the Volksraad to be the legislative power in the state and, as such, the "hoogste gezag" (highest authority). This did not mean, as he had erroneously decided in Executors of McCorkindale v Bok NO, ${ }^{37}$ that "the Volksraad, as the highest authority, is, in the sense of the absolute power, above the Grondwet". Rather, "the portion of the sovereign power [the King's voice] entrusted to the Volksraad by the people shall be exercised under and in accordance with the terms of the authority or mandate expressed in the Constitution". ${ }^{38}$ The crucial distinction between the highest authority of the Volksraad (established in the Grondwet) and the sovereign authority of the people (exercised by means of the Grondwet) is necessary to maintain free self-government based on the sovereignty of the people against a despotism that can arise if the most important agent of the state (the council of the representatives of the people: the Volksraad) declares itself to be, or acts as if it is, the state itself. The Grondwet is there to limit the exercise of power in the interests of the people. ${ }^{39}$ In this part of his judgement he quoted extensively from American jurisprudence, in particular from the 1885 decision of Poindexter $v$ Greenlow. ${ }^{40}$

The sovereign people, therefore, entrusted the highest (legislative) authority to the Volksraad through the medium of the Grondwet; it is from the Grondwet that the Volksraad derives its powers, the latter is not independent from it, and exercises its authority within the limitations that the former prescribes. ${ }^{41}$

It is within the province of another organ of state established by the Grondwet, the judiciary, to test the validity of a particular law by reference to the provisions of the Grondwet: "A Constitution is, in fact, and must be regarded by the judges, as a fundamental law." ${ }^{\prime 2}$ A popular government that exists under a constitution (such as the Grondwet), has a fundamental law that prescribes the manner in which the legislature is to declare its will for it to have the force of law. The duty of the court is to test whether the legislature's expression of will is a law or not - in form, but also in substance. This right of the judicial organ of state to test the validity of the laws passed by another organ of state need not be expressly formulated in a constitution, and there is sufficient authority ${ }^{43}$ to assert that it arises by irresistible implication. ${ }^{44}$ Most eminent, most eloquent and most persuasive of the jurists he consulted was

(1884) 1 SAR 202. His judgement in McCorkindale is discussed in Van der Merwe 2018: 96-100.

38 Brown v Leyds NO (1897) 4 OR 17 at 26.

39 Idem 26-27.

$40 \quad 114$ US $270(1885)$ at 291.

41 Brown v Leyds NO (1897) 4 OR 17 at 27.

42 Idem 29.

43 In his judgement, Kotzé CJ references Roman-Dutch, Dutch, German, English and American law.

44 Brown v Leyds NO (1897) 4 OR 17 at 28-29 and 31 n "(u)". 
Marshall CJ, from whose famous judgement in Marbury $v$ Madison $^{45}$ he quoted a full page and a half in the reported judgement. ${ }^{46}$

Having thus provided meticulously for the jurisprudence to underpin his judgement, he proceeded to analyse the facts. The resolution of the Second Volksraad of 26 July 1895 was not law, because it was not introduced, considered, adopted and duly promulgated in the form prescribed by the Grondwet, the fundamental law of the state. A Volksraad resolution has no constitutional standing. ${ }^{47}$ To be sure, the rules of procedure of the Volksraad use language that suggests that laws and resolutions have the same legislative force, and the practice of the Volksraad over many years equally suggests that laws and resolutions are both treated as legislative enactments by the Volksraad. Such impressions, however, are erroneous. Neither rules of order, nor long and established practice, can alter the Grondwet. The Grondwet is binding upon the people, collectively and individually, until they have (here quoting the constitutional lawyer, Alexander Hamilton (1757-1804)) "by solemn and authoritative act annulled or changed the established form". ${ }^{48}$ Resolutions passed by the Volksraad bind the government, but - not being laws properly speaking - cannot bind the people: a distinction already drawn by SG Jorissen $\mathrm{J}$ in Trustees in the Insolvent Estate of Theodore Doms $v$ Bok NO. ${ }^{49}$

As the confirmation of the Executive Council proclamation of 20 July 1895 by the Second Volksraad was formulated as a resolution, and did not comply with the constitutional provisions for law-making, it had no legal standing. And it mattered not that section 32 of Law 4 of 1890 provided that resolutions of the Second Volksraad, duly published in the Government Gazette, were valid. This is because the Grondwet, the fundamental law of the state, provided that a resolution of the Volksraad does not have the force of law; if Law 4 of 1890 says it does, it is in conflict with the Grondwet and must yield to its fundamental authority. "If the Court is not at liberty to inquire into the constitutionality of Article 32," he asked rhetorically, "what becomes of the protection of the citizens vouchsafed to them by the Grondwet?"50

A resolution of the Second Volksraad validated the Executive Council proclamation that suspended the initial proclamation of 19 June of the eastern portion of the Witfontein farm as a public digging that would open on 19 July, and sought to deny Brown legal redress. This, however, was not valid law. Therefore, Robert Brown was entitled to be placed in as nearly as possible the same position in which he would have been on the morning of 19 July, had the responsible clerk allowed

455 US 137 (1803).

46 Brown v Leyds NO (1897) 4 OR 17 at 29-30.

47 Idem 34.

48 Idem 33.

49 (1887) 2 SAR 189 at 202-203. SG Jorissen J's judgement on this point is discussed in Van der Merwe 2018: 110-111.

50 Brown v Leyds NO (1897) 4 OR 17 at 34. 
him to purchase the licence that entitled him to peg off 1200 prospecting claims. Kotzé CJ ordered the responsible clerk to issue to Brown a prospecting licence for 1200 claims, upon payment being effected. ${ }^{51}$ Brown also claimed, in the alternative, astronomical damages of $£ 372000$ (around $£ 3.7 \mathrm{~m}$ in today's currency), ${ }^{52}$ should it no longer be possible to peg off the claims. ${ }^{53}$ Kotzé CJ ruled that if it became impossible for Brown to peg off all or some of the claims, the court would then hear evidence in order to determine the amount of damages. ${ }^{54}$

Ameshoff $\mathrm{J}$ and Morice $\mathrm{J}$ also delivered judgements, concurring in the finding of Kotzé CJ.

\section{The judgements of Ameshoff $\mathrm{J}$ and Morice $\mathrm{J}$}

Ameshoff $\mathrm{J}$ also found for Brown. ${ }^{55}$ The "great legal question" the court was called upon to decide, stated Ameshoff J, was whether the Supreme Court possessed the "testing right". ${ }^{56}$ The answer to this question depended on a determination of the natural meaning of the Grondwet provisions, bearing in mind that it was simpleminded farmers who had expressed their collective will in $1858 .{ }^{57}$ Through the mechanism of the Grondwet, the volk (the people), by virtue of their sovereignty (their exercise of the King's voice, he might have said), conferred four powers or mandates: legislative, judicial, executive and military. Of these, the "highest power" was entrusted to the Volksraad. This meant no more than that the laws it makes, affects the people directly and it therefore stood under the direct supervision of the people themselves, unlike the other powers. It did not mean a sovereign, unchecked power.

A careful, "natural" reading of the Grondwet allowed one to conclude that "a spirit of delegation, a spirit of conferring and entrusting, breathes through the whole

51 Idem 37-38.

52 See Van der Merwe 2015: ix-x for the method of calculation used to determine the modern monetary equivalent. At the time, it was thought that the Witfontein goldfield was situated on deep levels of the main reef, therefore worth between $£ 200-£ 400$ per claim. This later proved to be an erroneous assumption, and the claims were deemed to be of little value.

53 On 30 August 1895, the Witfontein farm was re-proclaimed a public goldfield, at which date claims were issued on the basis of a lottery system. Brown did not participate. See Van der Merwe 2018: 129.

54 Brown v Leyds NO (1897) 4 OR 17 at 38. Brown also, in the same action, claimed the right to peg off 800 claims on the nearby Luipaardsvlei farm on Monday 22 July 1895 , which right had also been denied him on the same basis as in respect of Witfontein. Since the proclamation suspending the opening of the goldfields on both farms had been issued on 20 July 1895, ie, before the Luipaardsvlei goldfields had been opened, the government was within its rights to withdraw a proclamation that had not yet come into effect. Kotzé CJ therefore dismissed Brown's claim in respect of the Luipaardsvlei claims. See idem 38-41.

55 His judgement is reported at idem 41-54.

56 Idem 41.

57 Idem 49-50. 
law". ${ }^{58}$ To the judicial power was assigned the authority to act according to the laws and to apply the laws as their judgement and conscience dictates. To "act according to the law" (as provided for in art 15) is to exercise its mandate to apply the law, to make sure that not one of the powers or mandates entrusted to the different organs of state is exceeded. That meant to apply the provisions of the Gold Law, to make sure the legislative and executive powers did not exceed their mandates by doing something the Gold Law did not allow (namely to suspend a proclamation of a goldfield in a manner not provided for by the Gold Law). Such a reading of the Grondwet reflected the spirit and natural harmony of the Grondwet. ${ }^{59}$ The court was constitutionally bound to apply the testing right: "I know without hesitation that I must exercise the testing right because of the conception I have of my duty." ${ }^{60} \mathrm{He}$ came to the same conclusions as Kotzé $\mathrm{CJ}$ and therefore concurred with his findings.

Morice J, too, found for Brown. ${ }^{61}$ When the resolution of the Second Volksraad of 26 July (later confirmed by the resolution of the First Volksraad of 1 August) was passed, Brown had already (on 22 July) had a summons issued in the matter, and the action had therefore commenced. Now, although the common law did provide for a law to be applied to pending cases, the Volksraad was not all-powerful. The Grondwet provided for a separation of powers; the power of the Volksraad did not extend to an infringement of the judicial power, which would be the case if it sought to meddle with cases already before the court. If it was unequivocally clear that the resolution sought to interfere in a pending matter, then he would have been called upon to decide whether such a resolution infringed the separation of powers, and therefore the spirit, embedded in the Grondwet. As this was not clear from the wording of the resolution, he was able to find that the resolution did not apply to Brown. ${ }^{62}$

At stake, then, was only the question whether the Executive Council proclamation of 20 July, suspending the proclamation of 19 July that the Witfontein public digging would be open on 19 July, was valid in law. As the proclamation was only published the next day, it had no legal effect on the events of 19 July. ${ }^{63}$ Brown was therefore entirely within his rights to demand a licence for the pegging off of his claims, against payment of the monies due, which he had done. To be clear, the judge wrote, he had no right to the land itself on which he had pegged off his claims, only to a right to be placed in the same position as if he had not yet pegged off land. The clerk must therefore issue a licence to Brown for 1200 prospecting claims on Witfontein, which is what he should have done on 19 July. ${ }^{64}$

Idem 51.

59 Idem 52-53.

60 Idem 54.

61 His judgement is reported at idem 54-65.

62 Idem 59-61.

63 Idem 59.

64 Idem 62. 


\section{Assessment of the judgements}

In Kotzé CJ's desire to promote the cause of an American-style constitutional democracy ${ }^{65}$ as a bulwark against Kruger's factional and populist politics, he was too ready to attribute to the 1858 Grondwet characteristics it simply did not possess. It was not a fundamental law, not in the sense of the US Constitution. It was meant to be and always treated as such by the people themselves and their mandatories - a living, malleable document, to regulate the orderly exercise of the legislative, executive and judicial powers of government. The people expressly decreed, in articles 12 and 29, that to the Volksraad shall be delegated the "hoogste gezag" (the highest authority) in the state, apart from its power to legislate. ${ }^{66}$ The people built into the Grondwet checks and balances to ensure that its highest authority was not abused, the most important of which was biennial representative elections and the right to petition the Volksraad on issues of concern. Het volk (the people) were the ultimate custodians of the state, and of the freedoms and independence of the individuals that constituted the state: not the Volksraad and certainly not the Grondwet, a mere instrument for the expression of the will of the people.

It had no higher status than an ordinary law, however much John Kotzé wished to assign this status to it, and however beneficial to good government it would have been had this been the case. There was no special procedure prescribed for its amendment; the people did not oppose its regular amendment, even by means of resolutions; the people were not dissatisfied with expressions of legislative will by means of resolutions. The Grondwet was simply not designed as, or meant to be, a vehicle to test the validity of the manner of the Volksraad's exercise of its legislative mandate.

Ameshoff J's insistence that the assignment by the people of the "highest power" in the state to the Volksraad was no more than an indication that its power was of a higher order than executive, judicial and military power. This was so, because of the immediacy of the impact of law-making on the people and therefore the need for direct popular supervision. It did not mean that the judicial power to act according to the law (granted in art 15$)^{67}$ was subordinate to that highest power, because that would offend the natural meaning of article 15. Ameshoff $J$ is misguided here. The

65 Since Kotzé's first judgement on the validity of Volksraad resolutions, in Executors of McCorkindale v Bok NO (1884) 1 SAR 202, he had consistently referenced the nature and role of the US Constitution in the US body politic. This was so, because the US was a republic, like the South African Republic, and also because the South African Republic, unlike in Great Britain, had a written constitution, approved by the people, on the basis of which the state was constituted. The manner in which the much-lauded US Constitution guided and determined state governance in the US, wholly encapsulated the ideal state structure (providing, as it did, for judicial review, which Kotzé sought to imprint onto the South African Republic's Constitution).

66 See the actual wording of arts 12 and 29 of the 1858 Grondwet as published in Jeppe and Kotzé 1887: 36 and 38 .

67 See Jeppe and Kotzé 1887: 36. 
"natural meaning" of "highest authority" as provided for in articles 12 and 29, and as interpreted in the light of the historical circumstances leading up to the approval of the Grondwet in 1858, was that the people consciously and deliberately granted to the Volksraad the authority to make laws and to exercise an authority that superseded all other authority - until the sovereign people saw fit to rein in that authority (to exercise their King's voice). The Volksraad was supreme, its authority unfettered by any other authority, circumscribed only by the people's sovereign fiat. If it legislated beyond the manner provided for in the Grondwet, the people, not the judiciary or the executive, would intervene - which had not happened.

Morice J's judgement was a deft, but flawed, side-step of the real constitutional issue confronting the Supreme Court. It was mere artifice on his part to argue that the Second Volksraad resolution did not explicitly interfere in Robert Brown's action - it undoubtedly did, no one disputed this at the time. It was also mere artifice to conclude from this that, since there was no explicit attempt to breach the separate power of the judiciary, it was not required of him to determine whether or not the resolution sullied the spirit of the Grondwet. Why should Morice J attach any significance to the spirit of the Grondwet anyhow, if it makes no mention of resolutions (except tangentially) and if it had no superior status to any other law or resolution? It can only be because he himself recognised that it mattered - and should therefore have been decided by him - whether the Grondwet could be altered (and its prescriptions for law-making ignored) by a resolution of the Volksraad. One surmises that Morice, a Scotsman and therefore an uitlander, albeit a tame one, did not wish to embroil himself in a constitutional controversy that had clear political overtones. He consequently adopted a technicist approach, one that was spurious.

\section{Reaction to Kotzé CJ's Brown judgement}

\section{Immediate political reaction}

Political reaction was immediate, as John Kotzé had no doubt foreseen. He was accused (by Willem Leyds, most notably) of having ulterior motives. He had made himself available as a candidate for the position of state secretary (the elections were to be held in May 1897). Having "criminally" (according to Leyds) provoked a constitutional crisis, the judgement would serve as a blueprint for how he would restore good government underpinned by constitutional principles embedded in the venerable 1858 Grondwet.$^{68}$ Kotzé later brushed aside these accusations "in silent contempt". ${ }^{69}$ The judgement was handed down in a period of heightened political animosity between the Republic and Great Britain. The dust had not yet settled after 
the Jameson Raid. The British parliamentary committee of inquiry into the Raid was then still underway. Rhodes, seeking to justify his complicity in the Raid, cited the judgement as an example of how poorly the Republic was governed and Joseph Chamberlain urged the committee to deliberate within the context of unresolved uitlander grievances. ${ }^{70}$

It was, from the perspective of internal politics, also not a good time for the court to depict the government as incompetent and to hand a victory to an uitlander (Brown). The finding of the majority that Volksraad resolutions had no force of law, meant that the majority of the legislation passed by the Volksraad (including legislation regulating the mining industry, like the Gold Law) had no validity. This further heightened the sense of incompetence and uncertainty surrounding the manner in which the state conducted its affairs. The prospect of the state having to pay damages to Brown in excess of $£ 300000$ was daunting; it was a massive sum, and such money was best spent on alleviating the economic woes of a Boer population in the grip of drought and disease. ${ }^{71}$

Paul Kruger called for an extraordinary sitting of the Volksraad in February 1897. Some 2000 burghers petitioned the Volksraad to dismiss Kotzé and Ameshoff. ${ }^{72}$ There was little sympathy for Kotzé, even among the Boer progressives. Kotzé himself saw no reason for alarm: "The plain road to ... [travel]", he wrote, was to identify all those resolutions that fell foul of the judgement, to re-cast them in the appropriate constitutionally mandated form and to place them before the Volksraad for its immediate adoption. ${ }^{73}$

A law, hastily drafted by State Secretary Leyds and State Attorney Coster, was presented to the Volksraad by State President Kruger to combat Kotzé's (and Ameshoff's) judicial overreach. It was passed on 26 February by a significant majority (twenty-two votes to four) and published as Law 1 of 1897 in the Government Gazette of 3 March 1897. ${ }^{74}$ The substance of the law (which came to be called the Testing Right Law) was located in four sections. Section 1 denied to the judiciary the competence to exercise a testing right (a right it was said never to have had and which was not defined); a judicial oath was prescribed in section 2, namely that a judge, prior to appointment, had to swear not to arrogate to himself the testing right; should a judge nevertheless exercise the testing right, section 3 provided that he would be charged with misconduct in his official capacity and tried before a special court (the same court that tried Benny de Korte in 1895); and section 4 granted to the state president the right to formally ask each of the current judges if he deemed it his duty to administer justice in accordance with the existing and future laws

70 See Botha 1926: 83-84; Marais 1961: 138 and 144; and Van Niekerk 1985: 120.

71 See Anonymous 1898: 107; Botha 1926: 87-90; and Marais 1961: 136.

72 See Botha 1926: 68.

73 Kotzé, CJ “An appeal to the inhabitants of the South African Republic" in Kotzé 1941: 278.

74 See Tindall in Kotzé 1941: xviii. 
and resolutions and not to exercise the testing right - should he fail to answer in the affirmative, he could be summarily dismissed by the state president. Section 6 , furthermore, guaranteed rights acquired through judgements of the Supreme Court before the law took effect.

Already on 23 February, when the law was still under discussion, Kotzé and his four fellow judges wrote a letter to the state secretary. ${ }^{75}$ The proposed law, they wrote, infringed on the independence of the judiciary (Kotzé in his correspondence always referred to it as "the so-called law"). Best to postpone its discussion (there is no reason for haste) and to rather appoint a Volksraad committee (which the judges would gladly assist) to investigate the effects of the judgement and to seek input from the people on the resolution of the problem. They also issued a public statement on the same day. ${ }^{76}$ They reiterated their view that the proposed law infringed their independence, said they would cooperate with the government to remove any "difficulties" caused by the judgement, and warned that they would adjourn the court sine die and appeal to the people if the law was adopted or if the Volksraad discussions infringed judicial dignity.

There was no consensus among the judges, however, on how the effects of the judgement were to be countered. The judges were given until 26 February to present solutions or to lodge their objections to the proposed law. None was forthcoming. ${ }^{77}$

A three-day debate in the Volksraad ensued, in which, according to Kotzé, the members engaged in "bitter mother-wit and petty malice". ${ }^{78}$ In the debate, both Leyds and Kruger insisted that the judgement would stand and Brown's rights would not be infringed upon..$^{79}$ Leyds urged the Volksraad not to heed the judges' advice to postpone the law and to seek input from the people: no impression should be created that the judges were co-determinants of law-making; there was no guarantee that the judges would not again assert the testing right; and, as the law was simply an affirmation of an existing state of affairs (no testing right ever existed), the participation of the people was not required ${ }^{80}$ In his contribution to the debate, Kruger repeated his political mantra: only the people - not the judiciary - can reject laws once made by the highest authority in the land, the Volksraad. In the people alone resides sovereign authority: het volk is Koning, he twice reiterated. The judges are free, as a fish is free, to swim in the laws and write judgements on them; but they cannot reject the laws of the highest authority. ${ }^{81}$

See Kotzé 1898: 6-7. See, too, Kotzé, CJ "An appeal to the inhabitants of the South African Republic" in Kotzé 1941: 279; and Tindall in Kotzé 1941: xvii-xviii.

76 See Kotzé 1898: 5-6.

77 See the exchange of correspondence published in idem 7-10.

78 As quoted by Gordon 1898: 358.

79 See Botha 1926: 87; see, too, Gordon 1898: 350.

80 See Botha 1926: 90-92; Van Niekerk 1985: 121-122; see, also, Marais 1961: 145.

81 See Smit 1951: 180-181; Kleynhans 1966: 23-24. 
The judges soon responded. They issued a statement from the bench on 1 March. The law, they stated, violated judicial independence, potentially even the liberty of the Republic, and exposed judges to suspicions of bribery. They would adjourn the court on 5 March indefinitely, until the will of the people had been heard. ${ }^{82}$ Gregorowski $\mathrm{J}$ stated that no man of honour could occupy a seat on the bench while the law was on the statute book. ${ }^{83}$ Kotzé told the British Agent, Conyngham Greene, that in his view the law was a contravention of the London Convention. A group of thirty-nine lawyers in Johannesburg condemned the law as a dangerous infringement of judicial independence. The Pretoria Bar remained silent on the matter. ${ }^{84}$

Undeterred, on 4 March Leyds, on behalf of Kruger, put to the three judges among the five who publicly claimed the testing right (Kotzé, Ameshoff and Jorissen) the question provided for in section 4 of Law 1 of 1897 . When the judges protested that they should all be treated equally, the question was duly put to Morice and Gregorowski too. They were given until 17 March to reply, despite their earnest entreaty that the letters be withdrawn "in the interests of the rights of the sovereign people". ${ }^{85}$ In fulfilment of their threat to adjourn the court, they indicated that none was available for the upcoming March circuit. Leyds duly had Esser (the same Esser whose acting appointment had been terminated by the court in November 1895) appointed as an acting judge to attend to the circuit. ${ }^{86}$

\section{Mediation by Chief Justice Henry de Villiers}

John Kotzé had earlier written to Sir Henry de Villiers, the chief justice of the Cape Colony, to solicit his support and those of other southern African judges. De Villiers declined to provide his support (he in fact disagreed with the approach adopted by Kotzé in Brown). He did offer to mediate in what had become a very public and unsavoury stand-off between the government and the judiciary in the Republic, an offer readily accepted. ${ }^{87}$

De Villiers arrived in Pretoria on 15 March, two days before the deadline for answering the question posed to them by the state president. He first met with the judges (at the time, Kruger was in Bloemfontein on a state visit), who rejected his proposal that they acquiesce in the provisions of the Testing Right Law. He met with

82 See Kotzé 1898: 12-13.

83 See Kotzé, CJ "An appeal to the inhabitants of the South African Republic" in Kotzé 1941: 284; and Nathan 1941: 409.

84 The British Resident, Conyngham Greene, in a letter to Alfred Milner, called the Bar's businessas-usual attitude a "pitiful exhibition" of craven submission to President Kruger's authority: see Headlam 1931: 217.

85 See Kotzé 1898: 14-15.

86 See idem 15-17; and Botha 1926: 70-71. On Esser, see Roberts 1942: 359.

87 See Walker 1925: 290-291. 
Kruger on 18 March and recorded his conversation with him in a detailed minute which was later published in the Cape Times. ${ }^{88}$

De Villiers informed Kruger that he agreed that the judges had no testing right. He suggested, however, that the judges had a point that needed to be attended to. This was namely the practice of the legislature to simply alter the Grondwet provisions at will whenever resolutions are passed. He proposed that Kruger should introduce a measure to protect the Grondwet against ready deviation, by adopting a special procedure for its amendment, as was the case with the Free State Constitution. Kruger was not averse to introducing such a measure, but said to De Villiers that he would not bargain with the judges: they must first undertake not to exercise the testing right, and then he would consider a representation from them for a constitutional amendment. De Villiers's response was that the judges must come out of the "affair" with their honour intact. Kruger should therefore consider, not making a bargain, but coming to an understanding (a "verstandhouding") with the judges that did not amount to the setting of conditions by either party. Although initially reluctant, Kruger was eventually persuaded by De Villiers to give to the judges an undertaking that he will propose to the Volksraad that a special procedure for its amendment be introduced. He warned, though, that it would not happen in the forthcoming session of the Volksraad that commenced in May, as much preparatory work must be undertaken and the people must be consulted. De Villiers indicated to him that he was sure the judges would be satisfied if the proposal was tabled only in the 1898 session - a fatal error of judgement, as it turned out.

De Villiers met with the judges on the same day as his interview with Kruger. A draft undertaking composed by De Villiers was discussed. Kotzé, not unreasonably, wanted a three-month time limit set for the amendment to be introduced. They settled for a wording that stated that the amendment would be introduced "as speedily as possible". De Villiers was less than honest with Kotzé in this regard: he knew that Kruger would only introduce the amendment in the 1898 session, but did not inform Kotzé and his colleagues of this. Given the context of the earlier discussion on the time limit, Kotzé was under the impression that "as speedily as possible" meant just that: if not in three months, then soon thereafter, in any event still in $1897 .{ }^{89}$

A letter was duly sent to President Kruger by the judges on 19 March, in which they agreed not to test current and future Volksraad laws and regulations against the Grondwet. This agreement was conditional upon an understanding that Kruger would present a draft law to the Volksraad "zoo spoedig doenlijk" (as speedily as possible) that would provide for a special procedure to amend the Grondwet and would also provide for judicial independence. ${ }^{90} \mathrm{~A}$ cordial reply was sent to the judges, by Leyds

88 On the minute, see Tindall in Kotzé 1941: xxxvi-xxxviii; and Walker 1925: 295.

89 See Walker 1925: 310-311; see, too, Tindall in Kotzé 1941: xxxix-xl.

90 See Botha 1926: 73-74 for the original letter in Dutch. See, further, Kotzé 1898: 19-20; Walker 1925: 296; and Tindall in Kotzé 1941: xix-xx. 
on behalf of Kruger, which created the impression that the crisis had been averted and that, with the judges' assistance, the matter would be attended to. ${ }^{91}$ Kotzé even wrote a letter to those lawyers (almost exclusively from Johannesburg) who had supported the judges. In this letter he expressed optimism that a crisis had been averted and that an amicable arrangement was in place to ensure the triumph of truly constitutional and Republican principles.

\section{The storm between Kruger and Kotzé brews in 1898}

Kotzé's expectations were cruelly dashed. No judge was asked to provide drafting advice. No committee was appointed. When Kotzé was on leave in Cape Town in April, he found that De Villiers, in an address to the Cape Legislative Assembly, had publicly voiced his opposition to the stance Kotzé had taken in Brown. He had also written to Kruger to promote franchise reform in the Republic as a stronger imperative than the entrenchment of the Grondwet..$^{92}$ At the official opening of the 1898 Volksraad session at the beginning of May, which Kotzé had specially come up from Cape Town to attend, Kruger said not a single word about the crisis and its resolution. He merely indicated that a process would be proposed to attend to the matter of constitutional reform, with no details being provided. The elections for the position of state secretary took place. On the opening day of the session the results were announced: of the four candidates, Leyds received the vast majority of the votes (nineteen out of twenty-five); Kotzé received not a single vote, which pleased Leyds to no end. ${ }^{33}$

Kotzé was politically isolated. His plan to establish a constitutional republican democracy, with the (flawed) Grondwet as its cornerstone, and to drive his goal by means of the Brown judgement, was unravelling. Kruger's attitude was clear: he would not be manoeuvred politically by a (mere) judge, safe in the knowledge that his people would support him to the hilt. Kotzé, however, was nothing if not tenacious. He wrote to the state president on 6 May, in his personal capacity. ${ }^{94}$ In this letter he reminded Kruger of his undertaking and repeated his offer for the judges to assist in the drafting process. He received no reply.

He now sought support from elsewhere. He was in regular contact with Conyngham Greene and confided to him that he had reservations about De Villiers's role in the matter. ${ }^{95}$ On his return to Cape Town to continue his holiday, he twice met

91 See Kotzé 1898: 20-21 for the letter; and see, inter alia, Botha 1926: 84.

92 See Van Oordt 1898: 782-783; Walker 1925: 310-311; Headlam 1931: 79; and Marais 1961: 146 $\mathrm{n} 1$.

93 See Van Niekerk 1985: 182; and Bossenbroek 2012: 103.

94 See Kotzé 1898: 22-23.

95 See Headlam 1931: 79; Marais 1961: $146 \mathrm{n} 1$ and $191 \mathrm{nn} 5$ and 6. 
with Alfred Milner, then recently appointed as British high commissioner. He also met with Cecil Rhodes. ${ }^{96}$

On 31 May the Volksraad appointed a committee chaired by Executive Council member, ADW Wolmarans, to advise on amendments to the Grondwet. Such amendments were to be sweeping: not only a special procedure for its revision, but for a proper delineation of all branches of state and a removal from it of all superfluous provisions and the retention of immutable provisions only. The brief of the committee was also to oversee a systematic and comprehensive compilation of all existing legislation. These terms of reference had been proposed by Kruger on 19 May. ${ }^{97}$ Clearly, the committee would not finish its work in the current session: Kruger had obviously seen to it that the protection of judicial independence and the entrenchment of the Grondwet, the basis of his undertaking to the judges in March, were subsumed under a broader project, thus diluting its primacy.

Kotzé telegraphed to De Villiers about Kruger's machinations and intimated that he would consider withdrawing from the March undertaking. De Villiers, about to set sail for London, where he was to be appointed as Privy Councillor, counselled him against precipitate action. ${ }^{98} \mathrm{He}$ also said that he had sent him a copy of the minute he had written when he met with Kruger. Upon reading the minute, Kotzé realised that De Villiers had never informed the judges that he had advised Kruger that there was no rush, that the amendments could readily serve only in 1898. Kotzé felt betrayed by De Villiers. ${ }^{99}$

On 9 June the cornerstone of the Pretoria Palace of Justice was laid. It would later become the iconic home of the Supreme Court. Kruger officiated at the ceremony, not the chief justice. Kotzé, who had played no small part in its design, was deliberately snubbed. ${ }^{100} \mathrm{He}$ continued to keep company with the opponents of those from whom he had been alienated: to Conyngham Greene he expressed "warlike" intentions to withdraw from his undertaking to Kruger; to Percy FitzPatrick, no friend of Kruger's Boers, he expressed the hope that "the imperial factor will prove to be the salvation of South Africa". ${ }^{101}$

Kotzé once more wrote to Kruger, on 8 July. ${ }^{102}$ In this letter he dispensed with diplomatic niceties. "You have departed from your undertaking", he wrote. "You have not consulted with the judges, the brief of the Volksraad committee is so wide

96 See Walker 1925: 311; and Marais 1961: 191-192. Milner's withering back-hander was that Kotzé was "not a strong man", but "useful". He lacked the political charisma to gather strong support for his views, but the avowed anti-Kruger sentiments of the country's chief justice made him "useful" to the British cause.

97 See Smit 1951: 181.

98 See Walker 1925: 311-312.

99 See Kotzé 1898: 23-24; Walker 1925: 311-312; and Tindall in Kotzé 1941: xxxix-xl.

100 See Le Roux 2003: 59-61.

101 See Headlam 1931: 82; and Marais 1961: 191-192.

102 See Kotzé 1898: 24-29. See, too, Botha 1926: 75-76; Tindall in Kotzé 1941: xxiv-xxvii. 
and its work subject to no clear timeline: all this points to one who has reneged on his undertaking." He implored him to request the committee to focus first and foremost on the constitutional amendments, which, he said, could be dealt with expeditiously. He wrote the letter in his personal capacity - the other judges had indicated they would wait until the end of the Volksraad session. ${ }^{103}$ The letter had one desired effect. The chairman of the committee wrote to Kotzé, asking for the names of judges willing to assist the committee in its task. Kotzé forwarded the latter to each of the judges. Only Esser volunteered his services; some said the chief justice should nominate the judges; some declined. Kotzé also declined to become a member of the committee, because of the presence of Leyds and Coster on the committee, but would provide advice when asked to do so. ${ }^{104}$

A reply to Kotzé's letter was sent on 16 July. ${ }^{105}$ In it, Kotzé's insistence that the undertaking was departed from was disputed; in fact, it said, the committee-based approach then underway was fully in line with the undertaking to act as speedily as possible. The committee could well present proposed amendments before all the laws were codified, there was no problem in doing so. In a snide concluding remark, it was stated that the other judges clearly did not see the need to correspond with the state president on this matter, since they were prepared to accept the bona fides of the president.

The increasingly fractious correspondence between Kotzé and Kruger's government took place against a backdrop of political and economic problems of such magnitude as to relegate Kotzé's concerns to a side-show - and an irritating one at that. In mid-year, the British parliamentary inquiry into the Jameson Raid tabled its report. Shamefully, it amounted to a whitewash of Chamberlain and gave Rhodes no more than a stern reprimand. ${ }^{106}$ Chamberlain's diplomatic offensive against the Republic had focussed on a string of imputed breaches by the Republic of the London Convention. The Republic had rebutted these accusations in April and had suggested that the dispute be submitted to international arbitration. ${ }^{107}$ Chamberlain's response, in October, was that the Republic was Britain's suzerain and as such would not stoop to arbitration with a subordinate. ${ }^{108}$

103 See, further, Kotzé, JG “An appeal to the inhabitants of the South African Republic” in Kotzé 1941: 286-287.

104 See Kotzé 1898: 33-34 and 38-42. See, also, Kotzé, JG “An appeal to the inhabitants of the South African Republic" in Kotzé 1941: 287-288; Botha 1926: 76-77; and Tindall in Kotzé 1941: xxixxxxi.

105 See Kotzé 1898: 29-33; see, also, Botha 1926: 76; and Tindall in Kotzé 1941: xxvii-xxix.

106 See Marais' incisive analysis of the report: Marais 1961: 71-95. See, further, Meredith 2007: 335353.

107 The Republic's rebuttal is published in Van Oordt 1898: 869-894.

108 See Van Oordt 1898: 769-773; Walker: 1925: 314-315; Marais 1961: 195-200; and Bossenbroek 2012: 97-106. 
The country was in the grip of a severe drought, a rinderpest epidemic and a recession in the mining industry. ${ }^{109} \mathrm{An}$ industrial commission had been established by the Volksraad in April, to investigate reforms in the industry. Much was expected of it, as a vehicle to bring about much-needed economic reforms and to lessen the tensions between the government and the uitlanders. Little came of it, though; the piecemeal reforms eventually approved by the Volksraad (Kruger actively participated in the debates) did little to ease political tensions and to liberalise the economy. ${ }^{110}$

True to form, Kotzé pursued his quest, undaunted by events. In August he met with High Commissioner Milner in Cape Town. Milner was given the impression that Kotzé was intent upon pursuing his crusade to breaking point, with or without the support of his fellow judges, and even if it meant him losing his position. ${ }^{111}$

Towards the end of August, Kotzé was called upon to adjudicate in a matter that had run parallel with the Brown matter. One Rothkugel had, like Brown, also pegged off claims on the Witfontein farm on 19 July 1895. One month after the Brown judgement, in February 1897, the supreme court had given judgement in Rothkugel's favour, finding that his action was on all fours with that of Brown. Rothkugel, more anxious than Brown to exercise the rights granted to him, had bought a licence in March and tried to peg off his 400 claims on Witfontein. He was refused permission, as the claims had already been awarded by lot to others in August 1895. In June, Rothkugel approached the court (Kotzé CJ, Morice J and Jorissen J presided) to demand $£ 125000$ damages from the state. He did this, not through the issue of a new summons, but by way of a notice that he would present evidence to substantiate his claim for damages. The state's objection to this process was dismissed by Kotzé CJ. The clear intention of the court in February had been that, if the claims could not be pegged off, then the same case should be further heard to determine damages, and finally disposed of. ${ }^{112}$

Judgement was rendered on 23 August 1897. ${ }^{113}$ Kotzé CJ expressed himself satisfied with the evidence produced to determine the fair market value of the claims, based on the proximity or otherwise to the probable location of the main reef. He was satisfied that the value of the claims was $£ 6$ 500. Morice J concurred with Kotzé CJ. EJP Jorissen J was far more sceptical of the credence of the speculative and contradictory evidence presented to the court, so much so that he was unable to determine a fair or even speculative market value. His award of $£ 1750$ amounted to nominal damages only. It is difficult to escape the conclusion that Kotzé CJ was

109 See Van Oordt 1898: 785-786.

110 Idem 773-781; Nathan 1941: 388-390; Marais 1961: 189-195; and Van Niekerk 1985: 135137.

111 See Headlam 1931: 82-83, 89 and 114.

112 See Kotzé CJ's notes of the proceedings, published in $R G$ 76: at 201. See, further, Jorissen and Morice JJ's notes at 215 and 216.

113 Elias Syndicate v Leyds (1897) 4 OR 248. 
willing to lend credence to speculative evidence, far more so than Jorissen J, in order to make an award against the state in the Witfontein matter, an award that, though not meant to sting, would send a message to Kruger and his obstinate bureaucrats.

On 16 September, Kotzé again wrote to President Kruger, a belated reply to the 16 July letter. ${ }^{114}$ His purpose throughout, stated Kotze, was to make sure that the understanding reached between them in March was adhered to, namely that Kruger would take expeditious steps to secure a Grondwet protected against sudden change and providing for the pure, worthy and independent administration of justice. $\mathrm{He}$ received no reply. In the same month he publicly repudiated De Villiers's statement on the Brown matter that had appeared in a London newspaper. ${ }^{115}$

\section{President Kruger dismisses his chief justice}

By the end of 1897 , Kotzé was determined to bring matters to a head. He was by now acting alone. The 1897 Volksraad session had concluded without so much as a progress report from the constitutional amendment committee appointed in May.

On 16 December, Kotzé wrote a terse note to the president. ${ }^{116}$ The understanding reached between us in March, he stated, was that you would submit recommendations to the Volksraad for the revision of the Grondwet for consideration by it and by the volk. Yet nothing has been presented. "Why", he asked with no little asperity, "have you departed from your undertaking and what do you propose to do about it?" Again, no reply. The presidential elections were to take place in early 1898 and Kruger had much more on his mind than his chief justice's petulance.

Kruger won the elections, far more convincingly than had at first been thought. ${ }^{117}$ Upon his return from his vacation in Cape Town, and soon after Kruger's election victory, Kotzé wrote his fateful letter to Kruger. ${ }^{118}$ "I have waited patiently", he wrote, "for you to uphold your side of the understanding reached between you and the judges in March 1897. Yet nothing has happened and there are no indications that anything is about to happen. The judges agreed not to exercise the testing right on the condition that you would introduce the revision measures as speedily as possible. [He of course knew that Kruger had indicated to De Villiers that he would introduce measures to the Volksraad in 1898, so Kotzé was being disingenuous here.] Any undertaking is reciprocal in nature: since you did not fulfil your side of the undertaking, I hereby give notice that my undertaking not to exercise the testing right has lapsed. The understanding of March 1897 therefore no longer exists."

114 See Tindall in Kotzé 1941: xxxvi.

115 See Walker 1925: 317.

116 See Kotzé 1898: 45-46; and, also, Kotzé, JG “An appeal to the inhabitants of the South African Republic"in Kotzé 1941: 289.

117 See Nathan 1941: 412-413; and Marais 1961: 200-202.

118 See, among others, Kotzé 1898: 46-48. This is Kotzé's English translation of the original Dutch. 
Kotzé sent his letter to the bar and the side-bar. It made headlines, also in Cape Town. De Villiers had his minute of his meeting with Kruger published. ${ }^{119} \mathrm{He}$ wrote to Kotzé, expressing fraternal support, despite how Kotzé had misjudged him. Kotzé, in no mood for reconciliation, protested that De Villiers had been less then frank with him on more than one occasion. ${ }^{120}$

On 16 February 1898, Kruger responded. Incredibly, there had been no personal engagement between Kruger and Kotzé during this time. The statement made by the judges on 19 March 1897 and to which I responded positively, he wrote with no little of his own disingenuousness, cannot be construed as a contract - no judge can contract in and out of his duty to apply the law. Your statement that you regard the understanding to have lapsed in effect means that you did not answer positively to the question put to you in March in terms of section 4 of Law 1 of 1897. In terms of that section, therefore, and "to my great regret", you are discharged with immediate effect as chief justice. Kotzé's immediate protests that there had undoubtedly been an understanding with reciprocal obligations, that Kruger had breached the conditionality of the undertaking and that, if anything, Kotzé should be tried by a special court, rather than to be summarily dismissed, was rejected by Kruger ${ }^{121}$

No judge resigned in sympathy with Kotzé. Gregorowski, who had dramatically declared from the bench that no person of honour could occupy a seat on the bench while Law 1 of 1897 existed, ${ }^{122}$ was made chief justice. Esselen, leader of the bar, punted to replace Kotzé as chief justice, declined the offer. Ameshoff resigned, because he had been overlooked for the position of chief justice, not out of sympathy with Kotzé. ${ }^{123}$

Kotzé, typically, refused to lie down. He wrote to the bar that he would adjourn the court indefinitely. Leyds, the state secretary, thereupon informed the registrar that anyone who took instruction from Kotzé, rather than Gregorowski, would bear the consequences. ${ }^{124}$ In fact, the court would continue to function normally and, apart from a resolution of support passed by lawyers in Johannesburg, Kotzé's dismissal had no direct impact on judicial business. ${ }^{125} \mathrm{He}$ addressed a number of public meetings in Pretoria and Johannesburg, one of which was a testimonial dinner in his honour organised by the legal fraternity, and wrote articles in the press - not all of which did him credit. ${ }^{126}$

119 The minute was also published in the Cape Law Journal: see Editorial 1898a: 59-64.

120 See Walker 1925: 317-318; and Tindall in Kotzé 1941: xxxix-xl.

121 On the above, see Kotzé 1898: 50-54; Tindall in Kotzé 1941: xxxiv-xxxv.

122 See n 78 supra.

123 See Van Oordt 1898: 784; Botha 1926: 80; Editorial 1905: 488-489; Nathan 1941: 409; and Tindall in Kotzé 1941: xxii-xxiii and xxxvi.

124 See Botha 1926: 79-80.

125 See Kotzé 1898: 54-55; and Headlam 1931: 217.

126 See Van Oordt 1898: 785 n 1; Editorial 1898b: 92; and Van Niekerk 1985: 123. 
He began to practise at the bar, although he had told Milner in February ${ }^{127}$ that he would only do so - and thereby lend legitimacy to the judiciary - if compelled by necessity. He also told Milner that he would publish a manifesto of his grievances ("An appeal to the inhabitants of the South African Republic"), which he duly did. ${ }^{128}$ Furthermore, he informed Milner, since he would get no redress in the Republic, that he would take his cause to London. He did so: he went to London in April where, in an interview with Chamberlain, he sought the latter's support for his claim that his dismissal was in breach of the London Convention and that Britain, as the suzerain power, should intervene. As Milner had forecast, nothing came of his attempts to drum up British support. Kruger accused him of treasonous activity and Kotzé lost much of the sympathy many had for him. ${ }^{129}$

Kruger was not magnanimous in victory. At his inauguration on 12 May 1898 as the fourth state president of the South African Republic, Kruger in his inaugural address devoted some forty per cent of it to the judicial crisis. ${ }^{130} \mathrm{He}$ began as he had always done in his previous inaugural addresses: ${ }^{131}$ he stood before the volk, obedient to their call, in which he recognised the voice of God. ${ }^{132}$ He would lead them in His light and never, ever would he undermine their sacred independence. Under God's guidance a Volksraad was established and through it a Grondwet came into being. Article 8 of the Grondwet confirmed the greatest possible freedom of the people, a freedom that was not wanton, but based on God's word. ${ }^{133}$

Just as the people of Moses exercised their freedom within the confines of the Ten Commandments and of the laws made and applied by the wisest among them, so too in the Republic. ${ }^{134}$ In the exercise of its supreme authority, the Volksraad made laws and passed resolutions, which the judges were bound to apply according to their judgement and conscience, and which all others were bound to respect. Only the people themselves, in the exercise of their Koningstem (their King's voice) and guided in their thoughts and conscience by God's presence, could disapprove of a law. ${ }^{135}$

To assert the right to test laws that can only be changed by the supreme and sovereign authority that enacted them, was to arrogate to oneself the testing right that had been introduced to mankind by the Devil. God instructed Adam and Eve not to eat of the fruit of the tree of the knowledge of good and evil, upon pain of death.

127 Details of his interview with Milner are published in Headlam 1931: 216-217 and 224-226.

128 Kotzé, JG "An appeal to the inhabitants of the South African Republic" in Kotzé 1898: 289.

129 See Gordon 1898: 365-366; and Headlam 1931: 232.

130 The speech is published in Van Oordt 1898: 847-865. The paragraphs below contain some paraphrased parts of the speech.

131 See Du Plessis 1952: 41-54.

132 Van Oordt 1898: 848.

133 Idem 848-854.

134 See idem 855-861 for what follows.

135 Idem 857. 
The Devil tested them, by telling them that they will not die, but will become one with God and have no need of him. Under Moses, the testing right of the Devil was arrogated by Korah, Dathan and Abiram, who rose up against Moses and Aaron, leaders appointed by God. They disorganised the country and the resultant discord only abated when God destroyed them and their supporters. ${ }^{136}$

The testing right is the principle of the Devil. Once you allow it, discord and disorganisation inevitably follow. God's word teaches that those who assert for themselves a sovereignty they do not possess, and who do not remain within their allotted sphere of power, should be dismissed. Chief Justice Kotzé asserted the testing right and therefore had to be dismissed. He did not remain in his natural habitat - namely that of the laws and their application - but sought, like a fish, to jump out of his waters onto dry land. Just like a fish is too slippery to catch, so the chief justice proved to be when I (with the assistance of the Cape chief justice) tried to coax him back into the waters. ${ }^{137}$

The former chief justice stated that the crisis was all my doing, said Kruger, that I did not keep my promise. That is all nonsense, I gave him no promise, but did give him my word I would attend to matters as soon as possible, and that is what I did. But I no longer blame him, because he is not of sound mind (a statement he was to make twice more in his speech). He has the temerity to now seek British intervention, but his grounds are specious and he knows it. But I no longer blame him, because of his mental infirmity. I would that I could have him confined to an asylum for the insane, because if he were to recover, I would again use his valuable services. ${ }^{138}$ Let the whole world know that I did nothing wrong. Let the chief justice's dismissal be a valuable lesson to all, he concluded. The evil of testing the sovereign power of those appointed by the people under the protection of God must be contained.

Kotzé's response to this lengthy peroration was to call him an "oily old Chadband". ${ }^{139}$

The constitutional amendment committee presented its report in October 1898; it was debated in the 1899 session; and Grondwet amendments were passed only in late August 1899, two weeks before the outbreak of the Anglo-Boer War. Not one of the proposals that Kotzé had fought for, was accepted. ${ }^{140}$

Kotzé practised at the bar in Johannesburg until mid-1899 and at the bar in Grahamstown for a period from August 1899. He was attorney-general of Rhodesia from 1900 to 1903; judge and later judge-president of the Eastern Districts court from 1903 to 1912; judge and later judge-president of the Cape Provincial Division

136 Kruger's biblical references were to Genesis 2: 17 and 3: 5 and to Numbers 16.

137 Van Oordt 1898: 858-859.

138 Idem 860.

139 See Gordon 1898: 92. "Chadband" refers to the unctuous, self-serving evangelical clergyman promoting a false religiosity in Dickens's Bleak House.

140 See Botha 1926: 82; Thompson 1960: 71-72; and Marais 1961: 203 n 1. 
from 1913 to 1922; and, from 1922 to 1927, judge of the Appellate Division. He was knighted in 1917. He died on 1 April 1940, aged ninety. In a letter written not long before he died, he adopted a surprisingly magnanimous attitude towards Kruger: "I bear his memory no malice. He was the child and product of the veld ... 'The conceit of knowledge that springs from ignorance' was his undoing." 141 Kotzé is remembered today, not as a progressive constitutionalist and fighter for a constitutional democracy, but as a pre-eminent scholar of the Roman-Dutch law. ${ }^{142}$ He would, one suspects, have preferred his legacy to have been for the former rather than the latter.

\section{Jurisprudential reaction to the Brown judgement}

Very few of Kotzé's contemporaries in the legal fraternity shared his jurisprudential approach in Brown. One exception was JBM Hertzog, later Prime Minister of the Union of South Africa, and for a brief period in 1895, an advocate in Pretoria before becoming a judge in the Free State. ${ }^{43}$ Those who thought Kotzé's decision to be wrong in law included Sir Henry de Villiers, Ewald Esselen (who had always maintained the view he had expressed as a judge in Trustees in the Insolvent Estate of Theodore Doms v Bok NO), ${ }^{144}$ Jan Smuts - then a young advocate in Johannesburg and a later towering figure in national and international politics - and NJ de Wet, a young advocate who later became chief justice of the Union of South Africa. ${ }^{145}$

Two lawyers wrote erudite critiques of the judgement in 1898. The one contribution was published anonymously in the Cape Law Journal in 1898 (some say it was written by Jan Smuts) $)^{146}$ and the other, written by JW Gordon, was published in the Law Quarterly Review in London. ${ }^{147}$ Both were highly critical of Kotzé's judgement.

The anonymous critique began with the statement that when a legislature decides to express the public law and principles of a state in a constitutional enactment, that in itself does not elevate the enactment to a higher status than other laws. It will only be so if it is clear from the circumstances or from the provisions in the enactment itself. If not clear, then no exalted status attaches to it. ${ }^{148}$ Was the 1858 Grondwet an enactment with a higher status than other laws, as Kotzé CJ had found? The answer to such a question resided in an analysis of the facts that governed the approval of the Grondwet in February $1858 .{ }^{149}$ Did the Grondwet emanate directly

141 See Nathan 1941: 408-409.

142 On the biographical details of John Kotzé's later career, see Zimmermann and Sutherland 1999: 161-162.

143 See Tindall in Kotzé 1941: xxii-xxiii.

144 (1887) 2 SAR 189 at 192. See, too, Van der Merwe 2018: 109.

145 See Walker 1925: 318-320; Nathan 1941: 407-408; and Marais 1961: 203-204.

146 Anonymous 1898: 94-109.

147 Gordon 1898: 343-366.

148 Anonymous 1898: 95.

149 Idem 96-98. 
from the sovereign people, and was it their will that was expressed in it? If so, legal checks were indeed imposed on the legislature, but only if those limitation clauses had indeed the meaning that Kotzé CJ attached to them.

The author's detailed scrutiny of the events that had led to the approval of the Grondwet guided him to the conclusion that it was not the sovereign will of the people that was expressed in the Grondwet, but that it was the Volksraad that approved it and that gave the Grondwet legislative effect ("The sovereign people did not pass the Grondwet ... The Grondwet is the creature of the Raad ...). ${ }^{150}$ As argued in the first of this series of articles, this conclusion was wrong: it was in all respects an instrument of the people, executed through the will of the people. ${ }^{151}$

The author continued on safer ground when he provided abundant evidence that the Volksraad, with the concurrence of the people, had made regular amendments to the Grondwet in a manner not prescribed by it; also that resolutions were regularly and abundantly passed by the Volksraad. His analysis of the Grondwet leads to the correct conclusion that it was wrong to impute to it the immutability and definitiveness Kotzé CJ (and Ameshoff J) sought to ascribe to it. Law-making was indubitably the sole province of the Volksraad as the highest authority of the state, guided - but not defined - by the Grondwet, and by volk-approved legislative practice over a fortyyear period. The court had no authority, granted either by the Grondwet or by internal constitutional practice, to question the law-making powers of the Volksraad. ${ }^{152}$

The author furthermore took the view that the circumstances surrounding the withdrawal of the proclamation of the Witfontein goldfield and the manner in which the government dealt with the matter, did not warrant a departure from established precedent. The Volksraad resolutions were made in good faith in order to combat a state of unrest and the near-certainty of armed conflict, and did not directly impact on any vested rights that Brown then enjoyed. ${ }^{153}$ These are sound arguments.

Surprisingly, the author commended Morice J's judgement. ${ }^{154}$ As argued earlier, ${ }^{155}$ Morice $\mathrm{J}$ sought to base his argument on the wording of the resolution in question and thereby to avoid taking a view on the constitutional issue. However, when he appealed to the spirit of the Grondwet to assert that the Volksraad cannot, by resolution, interfere in an existing case, he implicitly elevated the Grondwet to a higher plane than other legislation. In so doing, he did in fact take a view on the constitutional issue, despite his desire not to do so. In any event, the Volksraad had done so before, with impunity, ${ }^{156}$ so why not in this case? Furthermore, it was abundantly clear that the resolution was aimed at interfering in the pending matter

150 Idem 105.

151 See Van der Merwe 2017: 162-163.

152 Gordon 1898: 98-104.

153 Idem 106-107.

154 Idem 107.

155 See the discussion at 3 supra.

156 In Executors of McCorkindale v Bok NO (1884) 1 SAR 202 and Trustees in the Insolvent Estate of Theodore Doms $v$ Bok NO (1887) 2 SAR 189. 
of Brown, so Morice J's assertion that it was not clear that it did so, was patently untenable.

The author, in conclusion, had little sympathy for Kotzé's plight. ${ }^{157} \mathrm{He}$ had brought it upon himself for he had acted in a manner that any state president would have found insupportable. Section 4 of Law 1 of 1897 was merely a shortcut to what a special court would have found anyway, so it was no use fulminating against that law. Furthermore, the state president had acted "with singular patience and forbearance". Kotzé deserved what happened to him, the same would have happened in any civilised country.

The second author, Gordon, in the Law Quarterly Review, made the initial important point in his critique that the Zuid-Afrikaansche Republiek, in common with Great Britain, had no "organic statute" that corresponded to what, in the United States and elsewhere, is captured in a Constitution. ${ }^{158}$ The "real" constitution of the Republic, he wrote insightfully, was "discernible in its statutes, routine of legislative, judicial, and official business, and historical connexion with older states, but it has never yet been codified, collected, or expounded". 159

After a detailed analysis of the circumstances surrounding the Brown matter, ${ }^{160}$ he analysed each of the judgements. He started with the judgement of Morice J, because he characterised it as "much the most intelligible utterance upon the issues raised" ${ }^{161}$ Although, as already stated, there is much to take issue with in Morice J's judgement, Gordon did refer to a feature of his judgement that bears scrutiny. "Ingeniously", wrote Gordon, "the judge tapped into a deeply ingrained conviction of the Boers, which was namely that the executive and the legislature should not interfere with the independence of the judiciary". Morice J appealed, in effect, to the independence of the judiciary and to the unconscionability of the Volksraad being seen to interfere in a matter pending before a court. He thus defeated the intention of the Volksraad in finding against it, which made, Gordon said, his judgement as sound in fact as in reason. ${ }^{162}$

As to Kotzé CJ's judgement, Gordon pointed out that the distinction he sought to draw between the Grondwet and any ordinary law was not apparent. ${ }^{163}$ From the circumstances under which, and the purposes for which, the Grondwet was drafted, it was irresistible to infer that the people at the time did not intend to draft a law that was immutable and irrefutable. In fact, they readily acquiesced in the constant amendments to it by means of ordinary legislation. Kotzé CJ's instincts were sound and his sentiment generous ("he felt keenly that public liberty was not safe in such

157 Anonymous 1898: 108.

158 Gordon 1898: 343-344.

159 Idem 344.

160 Idem 344-348.

161 Idem 348.

162 Idem 350.

163 Idem 356-357. 
incompetent hands"), ${ }^{164}$ but the approach he adopted reflected his lack of grasp of legal principle and his lack of understating of the political conditions inherent in the problem.

Gordon did not spare Kruger in his criticism of the president's handling of the affair. He "manufactured a constitutional crisis out of judicial blunder"; ${ }^{165}$ in passing Law 1 of 1897, he "knew perfectly well in his secret heart that the whole scheme was a complicated piece of hypocrisy" that deceived no one; ${ }^{166}$ and his protests that his dilatoriness in promoting constitutional reform measures did in fact amount to him keeping his promise, was mere "tedious mummery". ${ }^{167}$ His actions were lawless and brutal and the sooner it was appreciated that sovereign power should be wrenched from the feeble hands to which they have been entrusted, the better it would be for all. ${ }^{168}$

\section{Kotzé CJ's dismissal contributes to the outbreak of the Anglo-Boer War (1899-1902)}

Alfred Milner, the British high commissioner, saw John Kotzé's dismissal as chief justice of the South African Republic on 16 February 1898 as the destruction of judicial independence in the Republic and its subjection to the executive. ${ }^{169}$ On 23 February 1898, a week after the dismissal, he wrote to Chamberlain that the dismissal may lead to serious consequences for the whole of the southern African region and renders it desirable for Great Britain to review its relations with the South African Republic. He questioned the legality of the post-Kotzé composition of the Supreme Court and the validity of its judgements in respect of British subjects and African residents, a situation he described as "unsatisfactory and pregnant with future trouble". ${ }^{170}$

Milner was being deliberately alarmist in his dispatch to Chamberlain. The Kruger/Kotzé affair had always been about judges' competence to declare invalid laws made by the Volksraad and to do so on the basis of the Grondwet. Kotzé's concern for the independence of the judiciary had always only entailed declaring unconstitutional laws passed in opposition to the provisions of the Grondwet. Law 1 of 1897 , crude instrument though it was, was merely an affirmation of an existing state of affairs. It pertinently stated that the Brown judgement stood, and Kruger had been consistent in his defence of judicial independence over many years. ${ }^{171}$

164 Idem 357.

165 Idem 358.

166 Idem 362.

167 Ibid.

168 Idem 364-366.

169 See Marais 1961: 204-209.

170 Headlam 1931: 218.

171 Smit 1951: 173-175. 
However, the dismissal, coming as it did so soon after Paul Kruger had been reelected state president for a fourth term a month earlier, certainly meant that internal opposition to Paul Kruger was not strong enough to make a difference. Kotzé, though ineffectual, had been an authoritative voice of opposition, and Kruger had swept aside his political opponents in the elections. Milner decided - and also eventually brought an initially reluctant Chamberlain over to his point of view - that the "medieval race oligarchy" that governed the Transvaal was "too great a curse to all S. Africans to be allowed to exist". ${ }^{172}$ It was time for Britain to round upon them. ${ }^{173}$

An indirect consequence of Kotzé's dismissal in hastening the advent of war in October 1899 was the so-called Edgar affair. ${ }^{174}$ A policeman by the name of Jones, under the mistaken impression that an uitlander, Tom Edgar, whom he was in the process of arresting for drunk and disorderly conduct in Johannesburg, was about to attack him, shot and killed Edgar. The policeman, Jones, was tried for culpable homicide in March 1899. The judge was twenty-eight-year-old Antonie Kock, who had been appointed a judge in June 1898. He had been in practice for two years only, was the son of one of Kruger's staunchest supporters in the Executive Council, and his appointment was in line with a policy to appoint "sons of the soil" into prominent positions in the state. ${ }^{175} \mathrm{He}$ was unfit for judicial office and Kotzé, had he still been in office, would strenuously have opposed his appointment. He would also not have allowed one so raw and overtly nationalistic as Kock to preside over the trial of a Boer accused of shooting an uitlander. None other than advocate John Kotzé appeared for Jones. The nine-man jury found Jones not guilty, and Kock J found it necessary, in a courtroom filled with excitable uitlanders, to remark that he hoped the police would, under similar future circumstances, know how to do their duty. Milner informed Chamberlain that, in his view, the decision proved that British subjects would not be treated fairly when Boer and British interests clashed. The Edgar trial and verdict led to mass demonstrations and unrest that contributed in no small manner to the outbreak of hostilities in October 1899.

\section{$5 \quad$ Robert Brown's quest for justice amidst political turmoil}

\section{Brown's attempts to secure his right to the claims in court}

When the Brown judgement was handed down, Brown had already left South Africa and his affairs were managed by his friend, one Francis Oakes. Three days after

172 See Meredith 2007: 376-377, quoting from correspondence from Milner to Selborne, Chamberlain's under-secretary.

173 Idem 372-377 and 391-392.

174 On which see, among many, Nathan 1941: 419-422; Marais 1961: 237-243; Van der Merwe 1981: 13-14; and Meredith 2007: 389-390.

175 See Van der Merwe 1981: 12-13. See, too, Roberts 1942: 367. 
the Brown judgement was handed down, on 25 January 1897, Oakes applied to the responsible clerk at Witfontein for the licence that the court had ordered be granted to Brown for the 1200 claims he had applied for back in July $1895 .{ }^{176}$ According to established practice, he was issued with a provisional licence to peg off the claims; the licence would be renewed after one month once a diagram had been provided to the claims inspector in order for the validity of the claims to be verified. However, the licence was endorsed to the effect that "these claims cannot be renewed as they encroach upon 'owners' and 'vergunning' claims". Such an endorsed licence in reality had no legal effect, as it was incapable of being renewed. ${ }^{177}$

When Oakes presented to the claims inspector his diagram of the claims Brown had pegged off on 19 July 1895, the inspector informed Oakes in writing that almost all of the claims noted on the diagram encroached on other claims already awarded or upon water rights; it was therefore impossible for him to allocate any claims until he had a proper surveyor's diagram. Oakes and Brown's attorney, one Hofmeyr, came to the conclusion that the attitude of the inspector and his officials was "frivolous and untenable", that they were acting under instructions from "the executive" to be obstructionist and that any attempt to renew the licence would be fruitless. ${ }^{178}$

His next step was therefore to apply to the court for damages, as Kotzé CJ had intimated in his judgement. ${ }^{179}$ Unaccountably, Oakes lodged his application only nine months later, in December 1897. He did this by way of notice to the court for the hearing of further evidence and arguments on the nature and extent of the damages suffered by Brown - the same process adopted by Rothkugel in his application some five months previously. ${ }^{180}$ The matter was set down for hearing only in March 1898, more than a year after the clerk at Witfontein had issued the contentious licence to Oakes. ${ }^{181}$

The case was heard on 2 March 1898 by Jorissen, Esser and Reitz JJ and judgement was delivered the same day. ${ }^{182}$ The state argued that the procedure adopted was flawed and that a new summons should rather have been issued, in which pleadings were filed, stating the full circumstances of the matter, to which the state could then file appropriate counter pleadings. Despite persistent argument by Wessels on behalf of Brown that Elias served as precedent for the adoption of the procedure, and that the licence issued by the clerk was legally worthless, the court was unmoved. It was not persuaded that Brown had exhausted all his options in respect of the licence issued in January 1897; the state had not been given a fair opportunity to prove that it could have provided Brown with at least some claims

176 His application is published in $R G 76: 89$.

177 See idem 217.

178 Idem 88-97.

179 See Brown v Leyds NO (1897) 4 OR 17 at 38.

180 See the discussion of Elias Syndicate v Leyds NO (1897) 4 OR 248 at 43 supra.

181 See $R G 76: 52$ and 77.

182 The record of the judgement appears in idem 76-80. 
before damages were considered. The court therefore ordered Brown to take out a proper summons in which he indicated his claims by means of a surveyor's diagram, in order to prove and to resist damages in due manner. ${ }^{183}$

Oakes, on behalf of Brown, sought advice on what his next steps should be, and Wessels, his counsel, gave it as his opinion that "the decision was absolutely incorrect, absolutely against precedent and perfectly unjustifiable". His advice was for Brown not to pursue the matter any further, an opinion attorney Hofmeyr agreed with. ${ }^{184}$ Brown would have faced a difficulty if he had taken out a "proper summons", as ordered by the court. This was namely that he would have had to provide details of the circumstances under which the 1200 claims were originally pegged off. This would, conceivably, have afforded an opportunity for the state to argue that the decision in Brown was wrong: wrong, because it declared invalid laws and resolutions affecting the original pegging off of the claims that the current judges were enjoined, in terms of Law 1 of 1897, to regard as valid law. If the judges were then to declare the resolutions passed in 1895 by the Second and then the First Volksraad to have been good in law, Brown would be found never to have had a case.

Subsequently, and based on the opinions of Wessels and Hofmeyr, the judges were accused of bias in a later international arbitration hearing, ${ }^{185}$ of hostility towards Brown and of executive-mindedness. This might have been so, but a careful reading of the record of proceedings does not support these contentions. The sense one gets is that the court, in the pedantic attitude it adopted towards what the value of the endorsed licence might conceivably be when in fact it was substantively worthless, was not accommodating towards Brown, arguing form over substance. Brown's dilatoriness in seeking legal redress only nine months later might also have influenced the judges.

\section{Brown's pursuit of extra-judicial means of redress}

Oakes informed Brown that he should no longer pursue legal redress, but should rather seek the intervention of the British or United States governments. ${ }^{186}$ Brown estimated that he had spent a total of between $£ 20000$ to $£ 30000$ on planning for and pegging off the claims and on subsequent litigation. ${ }^{187} \mathrm{He}$ pursued this political solution with obsessive vigour.

In October 1898, Brown approached Joseph Chamberlain, the British colonial secretary, with a request that Great Britain, as the suzerain power in the Transvaal, should protect him against the denial of justice he had suffered at the hands of the

183 See idem 77.

184 Idem 146-148 (Wessels's opinion) and 169-172 (Hofmeyr's opinion).

185 See discussion infra.

186 See RG 76: 172-174.

187 See the information contained in affidavits, published in idem 172-186. 
Republican judiciary. Chamberlain directed him to the United States government. ${ }^{188}$ He wrote to the United States secretary of state soon afterwards, citing principles of international law in support of his claim for damages. ${ }^{189}$ Only two years later, in January 1901, did the secretary of state take action. He placed the matter before the United States senate. The senate sought advice on the matter from the South African Republic. Detailed documentation was supplied to its committee on foreign relations, not by the republican government, but by the Milner administration, the Transvaal having been annexed by Great Britain during the Anglo-Boer War in July $1900 .{ }^{190}$

The war in South Africa made it difficult to pursue the matter. Only in April 1902, with the end of the war in sight, did Brown's attorney, Thomas Galt, a Canadian, again take active steps. The staff of Alfred Milner, then administrator of the Transvaal, directed him to Attorney-General Solomon, with whom he met several times. Solomon was of the view that Brown should have pursued all legal avenues open to him, before making political representations. Galt's response was that Brown faced the prospect, if he did so, that his claims could be declared void $a b$ initio if he were to issue fresh summons. ${ }^{191}$ In June, Galt changed tack. He had been informed that the Milner administration would validate all titles to land in the Transvaal recognised prior to the war. Galt sought, not damages, but to lay claim to the land on which Brown had pegged off the claims. Solomon would have none of it and advised Milner that Brown first needed to exhaust all legal remedies still open to him. ${ }^{192}$ Further meetings with Milner and with Solomon in July proved fruitless. ${ }^{193} \mathrm{In}$ September of that year Galt wrote to Chamberlain, who was equally unresponsive. ${ }^{194}$

Eleven days after Chamberlain's dismissal of his petition, Brown died. He was only thirty-seven years old when he died in Phoenix, Arizona, on 3 October 1902. His father, mother and wife, sole beneficiaries of his estate, pursued the matter after his death. ${ }^{195}$ He persuaded the United States ambassador to Great Britain, JH Choate, to engage with the British foreign secretary, Lord Lansdowne, on the matter in May 1903. In his response in November 1903, Lansdown refuted any basis in international law for a claim by Brown against Great Britain: there are no rules or principles of international law that oblige a conquering state to take over the liabilities of a conquered state for unliquidated damages; nor to take over liabilities that arise from alleged corrupt or illegal action of that state in the administration of its justice. ${ }^{196}$

188 Idem 154-155.

189 Idem 181-186 (his correspondence was conducted for him by two lawyers from his hometown, Pennsylvania).

190 Idem 155-156.

191 Idem 150.

192 Idem 157-158.

193 Idem 151-156.

194 Idem 149-151.

195 See idem 17-20, 176-177 and 178-179.

196 Idem 159. 


\section{Brown's claim is referred to international arbitration}

The United States did not treat this as the final word on the matter. Brown's claim was added to a long list of claims of citizens of the United States against Great Britain, and of the claims of British citizens against the United States. After years of diplomatic negotiation, agreement was finally reached in October 1907 between the two countries on the nature of the mechanism for the peaceful resolution of these disputes and on the nature of the disputes to be submitted for resolution. This paved the way for a Special Agreement for the Submission to Arbitration of Pecuniary Claims Outstanding between the United States and Great Britain to be signed by the two countries in August 1910. This agreement was ratified only in April 1912. ${ }^{197}$

The special agreement established an arbitral tribunal to adjudicate upon the 140 claims that had been submitted for arbitration. The tribunal comprised a neutral umpire, Henry Fromageot, ${ }^{198}$ and one arbitrator from each country. The terms provided for the tribunal to make decisions based on certain "equities". Brown's claim was one of ten that fell into a category of an alleged denial of property rights of one country's citizens against the other country. ${ }^{199}$ The first meeting of the tribunal took place in Washington, DC in May 1913. Its activities were suspended because of the outbreak of the Great War of 1914-1919. It resumed its activities only in October 1923 and concluded its work in January 1926. ${ }^{200}$

The US filed its memorial on behalf of Robert E Brown in September 1913, ten years after Lord Lansdowne had rejected Brown's claim against Great Britain under international law. It claimed, on behalf of Brown, damages from Great Britain of $£ 330000$ (plus interest), based on its denial to Brown of the property rights acquired by Brown in the South African Republic. Great Britain filed its answer in February 1914. With the intercession of the war and its aftermath, the United States only filed its reply to the British answer in April 1923, to which the British submitted a responding memorandum in October 1923. ${ }^{201}$ Brown's claim was heard from 2 to 9 November 1923 and a final decision was handed down on 23 November. Legal finality on the Brown saga was therefore only reached some twenty-eight years after Brown had first, in July 1895, initiated his action in the Supreme Court in Pretoria against the state to secure his right to peg off his claims on the Witfontein farm.

197 See RIAA at 9-11.

198 (1864-1949). Fromageot later became a judge of the permanent court of international justice. On Fromageot see Permanent Court of International Justice Individual Judges $1930 \mathrm{sv}$ Fromageot, H.

199 Robert E Brown (United States) v Great Britain RIAA at 11-15.

200 See RG 76: 77.

201 The memorial, the answer, the reply and the responding memorandum make up the bulk of the documentation contained in the Washington textual reference archives at RG 76. 


\section{The international arbitral award: Robert E Brown (United States) v Great Britain RIAA (2006) VI 120}

The arbitral tribunal gave their judgement on 23 November 1923. It gave a detailed and accurate summary of the facts and the applicable law. ${ }^{202}$ In doing so, they noted the "wider significance" of the Brown judgement. ${ }^{203}$ Kotzé CJ's judgement was lauded for its exhibition of great industry and ability; the judicial crisis it precipitated led to "the virtual subjection of the High Court to the executive power" and Law 1 of 1897 was the prelude to a "state of legal anarchy, which ... eventually led to the armed intervention of Great Britain"; effective guarantees of the property rights of uitlanders disappeared and the capricious will of the executive was the sole authority of the land. This was an astonishingly naïve verdict on the consequences of the Brown judgement, and of Law 1 of 1897. As explained above, whatever the demerits of the judgement, Law 1 of 1897 and the manner of Kotzé's dismissal, judicial independence was not destroyed, legal anarchy did not rein, the capricious will of the executive was not the sole authority in the land, and the events did not lead to war (at least not directly).

The tribunal analysed the events when Brown applied for his licence after the Brown judgement and the eventual judgement against him in March 1898. It concluded that "the disposition to defeat Brown's claim at any cost was at once disclosed by the Government's attitude upon this hearing". It accepted the United States's argument that the court's insistence that Brown should issue a new summons was to effectively open the possibility that the original resolutions would be declared valid and that Brown would thus effectively be deprived of the benefit of the Brown judgement. ${ }^{204}$

The crucial question was whether there was a denial of justice? ${ }^{205}$ The tribunal's answer was an unequivocal yes. Brown had substantial rights entitling him to an interest in real property or to damages for the deprivation of those rights. It might be that "technical" arguments submitted by Great Britain had merit: that Brown did not acquire property rights; that Brown's pegging off on 19 July was in fact unlawful; and that Brown had not exhausted his legal remedies. These arguments, though conceivably valid, did not sway the arbitrators. In the first place, they were enjoined to make their decisions based on certain equities, and the circumstances called for such an approach. Secondly, it was incumbent upon them to take a "broader" view of the situation. The "cumulative strength" of the steps taken by the republican government "with the obvious intent" to defeat Brown's claims meant that a definite denial of justice took place. All three branches of government conspired to ruin Brown's claim to justice. Property rights became so insecure that it demanded intervention by Great

202 Robert E Brown (United States) v Great Britain RIAA 6 at 121-128.

203 Idem 124-126.

204 Idem 126-127.

205 Idem 128-131. 
Britain in the interests of elementary justice for all. Astonishingly, given the actual sequence of events, they found that annexation by Great Britain "became an act of political necessity" to enforce principles of justice and fair dealing in securing and respecting property rights.

If there was a denial of justice, could Brown's claim for damages succeed? The tribunal found that such a claim must fail. ${ }^{206}$ There were three interrelated reasons for the finding. In the first place, such a liability for damages never passed to or was assumed by Great Britain. Brown's claim was a pending claim against certain republican officials and never became a liquidated debt of the former Republic. Secondly, the nature and extent of the suzerainty that Great Britain exercised over the Republic did not mean that it assumed liability for wrongs committed by the Republic. Thirdly, there was no question of state succession involved. A successor state that acquires territory without a concomitant undertaking to assume its liabilities, is not bound to take steps to right the wrongs of the former entity. The tribunal, surprisingly, made no reference to principles of international law or to the opinions of international-law scholars in its decision. It was content merely to deflate the United States arguments related to suzerainty and to British officials' complicity in denying justice to Brown.

The tribunal therefore dismissed the United States claim on behalf of Robert Brown. In life, Brown had found himself a captive of a politico-constitutional power struggle between the state president and the chief justice of the South African Republic. In death, he was the victim, ostensibly, of an arrangement between two allies in a recent, catastrophic world war, that neither party should bear the brunt of a series of events in which it took no part. A finding that there had been a denial of justice, but that Britain should not provide reparation for it, was an even-handed approach that resonated with international "equities" - even if the facts had to be adapted to interpretations that bordered on the ridiculous to accommodate the result.

\section{Conclusion}

When one reflects on the events that led to the judgement in Brown v Leyds NO, the sobering conclusion one is forced to draw is that the major characters in the drama, John Kotzé, Paul Kruger and Robert Brown, lost all that they had set out with great determination to achieve.

John Kotzé's undoing was not lack of ability, not lack of dedication to his cause, not lack of moral and intellectual fortitude - it was his political ambition. He was a dedicated republican, truly desirous of seeking to achieve a fair deal for all in the immensely rich, but culturally backward, South African Republic of the 1890s. He chose, badly as it happened, to conduct what was essentially a political campaign from the bench. His not unreasonable desire was for true democratic principles to be entrenched in a constitution, as a bulwark against the more excessive chauvinist

206 Idem 129-131. 
politics adopted by Kruger and his supporters. The more his efforts were thwarted by Kruger's Realpolitik to protect the Boers, the more his conviction grew that he needed to take a stand in the forum in which he exercised true power - the court. But he chose his weapons for the campaign badly: the 1858 Grondwet could be massaged only so far and no further; and the government's genuine desire to avoid the real prospect of civil unrest at Witfontein was not unreasonable, however ham-fisted its approach might have been.

Undoubtedly, Kruger and his government treated Kotzé with something approaching disdain in the aftermath of the Brown judgement. But Kotzé did little to dispel a pervasive view that, throughout 1897 , he was acting with more petulance than judiciousness. He proved no political match for Kruger. In his efforts to secure support, he overplayed his hand: his overtures to Great Britain smacked of nothing other than an anti-republican sentiment that was unbecoming. Kotzé, a first-rate legal scholar and a proud servant of the Republic, deserved so much better than to become a victim of his own injudicious ambition.

Paul Kruger was correctly described by Kotzé as a child and product of the veld. From that perspective he was a formidable politician, outsmarting all in political acuity. The Witwatersrand goldfields and what they represented brought a dimension to Boer affairs that he was unable to properly deal with. His efforts to retain Boer independence for his volk and no one else, and to retain for them a sovereign voice, became increasingly clumsy and desperate. He retreated ever more into his theocratic comfort zone, in which a zealous reliance on the deity would nullify all opposition. It merely served to further stoke the fires of the opposition, both imperialist and progressive. His treatment of his chief justice in 1897 and 1898 was shameful, but not at odds with how he dealt with all political opposition. His obstinate refusal to make meaningful concessions to his political opponents, to give them a share in the sovereign voice, to protect at all costs a Boer independence that had little substance to it, was his undoing - and that of the volk on whom he staked his all. The AngloBoer War seriously hurt the Boer nation and caused them huge economic, emotional and physical hardship, and destroyed the ideals he had lived and fought for.

Robert E Brown, like so many others, had Virgil's "accursed thirst for gold". ${ }^{207}$ He staked his all, but, like Kotzé, he chose badly. Convinced that the main reef ran across the Witfontein farm, he spent a small fortune on planning for the 1200 claims he wished to peg off. It was all in vain. The claims later proved to be worth very little - the main reef ran further south of the farm. Then, when he sought to enforce what he believed to be his legal rights to the claims he had pegged off, he found himself an unwitting and very unwilling pawn in the power struggle between Kruger and Kotzé. When he sought to recoup his losses from Great Britain, he was stymied, first by the outbreak of the Anglo-Boer War, and later - much, much later - by the outbreak of the Great War. When, twenty-one years after his premature death, his claim was finally heard, it was clear that it would take much persuasion to convince an arbitral 
tribunal to make a substantial award for and against two allies (the United States of America and Great Britain) who had been through so much, based on a matter over which neither had any initial influence. Brown truly had justice denied to him, though not in the lugubrious terms described by the arbitral tribunal.

\section{BIBLIOGRAPHY}

Anonymous (1898) "Raad and Bench" Cape Law Journal 15: 94-109

Bossenbroek, M (2012) Die Boereoorlog (Afrikaans trl by A Mischke) (Amsterdam)

Botha, PR (1926) Die Staatkundige Ontwikkeling van die Suid-Afrikaanse Republiek onder Krüger en Leyds (Amsterdam)

Dictionary of South African Biography vol 3 (1978) (Durban) (cited as Dictionary of SA Biography vol 3)

Du Plessis, JS (1952) President Kruger aan die Woord (Bloemfontein)

Editorial (1898a) "The Transvaal judiciary" Cape Law Journal 15: 58-64

Editorial (1898b) "Chief Justice Kotze” Cape Law Journal 15: 90-93

Editorial (1905) “The late Mr Justice HA Ameshoff” SALJ 22: 488-489

Gordon, JW (1898) “The judicial crisis in the Transvaal” Law Quarterly Review 14: 343-366

Headlam, C (ed) (1931) The Milner Papers South Africa 1897-1899 vol 1 (London)

Jeppe, F \& Kotzé, JG (1887) De Locale Wetten der Zuid Afrikaansche Republiek 1849-1885 (Pretoria)

Jorissen, EJP (1897) Transvaalsche Herinneringen (Amsterdam)

Kahn, E (1959) "The history of the administration of justice in the South African Republic" SALJ 76: $46-57$

Kleynhans, WA (1966) Volksregering in die Zuid-Afrikaansche Republiek: Die Rol van Memories (Pretoria)

Kotzé, JG (1898) Documents and Correspondence Relating to the Judicial Crisis in the Transvaal (London)

Kotzé, JG (1941) Memoirs and Reminiscences vol 2 ed by BA Tindall (Cape Town)

Le Roux, L (2003) "Studying legal history through courtroom architecture: Scattered comments on the Palace of Justice, Church Square, Pretoria" Codicillus 43(2): 55-63

Marais, JS (1961) The Fall of Kruger's Republic (Oxford)

Meredith, M (2007) Diamonds, Gold and War (New York)

Nathan, M (1941) Paul Kruger His Life and Times (Durban)

Reports of International Arbitral Awards vol 6 (2006) United Nations [cited as RIAA]

Roberts, AA (1942) A South African Legal Bibliography (Pretoria)

Schagen van Leeuwen, JR (ed) (1897) De Locale Wetten der Zuid-Afrikaansche Republiek 1896 (Pretoria)

Smit, FP (1951) Die Staatsopvattinge van Paul Kruger (Pretoria)

Thompson, LM (1960) The Unification of South Africa 1902-1910 (Oxford)

Van der Merwe, C (2015) Donker Stroom (Cape Town) 
Van der Merwe, D (1979) "Skuld en skandaal in die hooggeregshof van die ZAR" 12: 242-251

Van der Merwe, D (1981) “The extraordinary life of Antonie Francois Kock" Codicillus 21(1): 9-17

Van der Merwe, D (2017) “Brown v Leyds NO (1897) 4 OR 17: A constitutional drama in four acts. Act one: The 1858 Constitution of the Zuid-Afrikaansche Republiek" Fundamina. A J of Legal History 23(1): 111-165

Van der Merwe, D (2018) “Brown v Leyds NO (1897) 4 OR 17: A constitutional drama in four acts. Act three: The King's voice speaks (differently) through the ZAR constitution to President and Chief Justice (1884-1895)" Fundamina. A J of Legal History 24(1): 89-133

Van Niekerk, LE (1985) Kruger se Regterhand. 'n Biografie van Dr WE Leyds (Pretoria)

Van Onselen, C (2017) Cowboy Capitalist (Johannesburg)

Van Oordt, JF (1898) Paul Kruger en de Opkomst der Zuid-Afrikaansche Republiek (Cape Town) Virgil Aeneid trl by D West (London)

Walker, EA (1925) Lord de Villiers and His Times South Africa 1842-1914 (London)

Zimmermann, R and Sutherland, P (1999) ““... a true science and not a feigned one': J.G. Kotzé (1849-1940), Chief Justice der Südafrikanischen Republik (Transvaal)" Zeitschrift der Savigny-Stiftung für Rechtsgeschichte 116: 147-194

\section{Cases}

Brown v Leyds NO (1897) 4 OR 17

Elias Syndicate v Leyds NO and the Responsible Clerk of Doornkop (1897) 4 OR 248-253

Executors of McCorkindale v Bok NO (1884) 1 SAR 202

Hess $v$ The State (1895) 2 OR 112

Snuif v The State (1895) 2 OR 294

Trustees in the Insolvent Estate of Theodore Doms v Bok NO (1887) 2 SAR 189

\section{United States Cases}

Marbury v Madison 5 US 137 (1803)

Poindexter v Greenlow 114 US 270 (1885)

\section{International cases}

Robert E Brown (United States) v Great Britain Reports of the International Arbitral Awards (2006) vol VI, 120 [cited as Robert E Brown (United States) v Great Britain RIAA 6]

\section{Archival sources}

Permanent Court of International Justice Individual Judges (1930) League of Nations Archive $R G$ 76: American and British Pecuniary Claims Arbitration: Robert E Brown (Claim no 30) National Archives, Washington DC, USA: Textual Reference Archives II Branch (RDT 2) [cited as $R G 76$ ] 